INTERNATIONAL REAL ESTATE REVIEW

2010 Vol. 13 No. 3: pp. $351-394$

\title{
The Housing Meltdown: Why Did It Happen in the United States?
}

\author{
Luci Ellis \\ Head of Financial Stability Department, Reserve Bank of Australia.Tel: +61-2- \\ 9551-8501; Fax: +61-2-9551-8032; E-mail: ellisl@rba.gov.au.
}

The crisis enveloping global financial markets since August 2007 was triggered by actual and prospective credit losses on US mortgages. Was the United States just unlucky to have been the first to experience a housing crisis? Or was it inherently more susceptible to one? I examine the limited international evidence available, to ask how the boom-bust cycle in the US housing market differed from elsewhere and what the underlying institutional drivers of these differences were. Compared with other countries, the United States seems to have: built up a larger overhang of excess housing supply; experienced a greater easing in mortgage lending standards; and ended up with a household sector more vulnerable to falling housing prices. Some of these outcomes seem to have been driven by tax, legal and regulatory systems that encouraged households to increase their leverage and permitted lenders to enable that development. Given the institutional background, it may have been that the US housing boom was always more likely to end badly than the booms elsewhere.

\section{Keywords}

Housing construction; Housing prices; Mortgage delinquencies; Mortgage markets; Subprime 


\section{Introduction}

The crisis enveloping global financial markets since August 2007 was triggered by actual and prospective credit losses on US mortgages. Could the crisis have started in another country's mortgage market as easily? There were so many other countries and markets where credit was booming and asset prices have been high. In many other countries, such as Australia, Canada, Ireland, Spain and the United Kingdom, housing prices were rising even more rapidly. Many observers at the time believed that this meant that the United States was less vulnerable to a housing bust than those other countries. The losses were propagated through the global financial system via trading in mortgage-backed securities (MBS) and related structured finance products; this propagation of the crisis is not the subject of this paper. Rather, the question posed here relates to the underlying defaults, and why they occurred in US mortgages, but not those from other countries.

I examine the background to the recent developments in the US housingfinance system, draw out some of the unusual features of this system, and compare with those in the other countries mentioned above. Based on this evidence, I conclude that the US mortgage market was uniquely vulnerable to the prospect of its boom ending badly. An autonomous escalation of delinquencies and defaults -that is, before a macroeconomic downturn- was not equally likely in all markets that had boomed in response to easy credit conditions.

The housing construction boom itself helped create this vulnerability. In contrast to some other countries, strong housing demand was met with additional supply that exceeded underlying needs. When the boom stopped, the United States was left with an overhang of excess supply that other countries have not built up. In addition, the easing in US lending standards seems to have gone further than elsewhere, across a number of dimensions such as documentation standards, loan-to-valuation (LTV) ratios (including second mortgages) and loans where principal was not paid down in the early stages of their lives. An unusually large fraction of long-standing homeowners therefore ended up with no or negative equity in their properties. As a result, mortgage arrears rates rose in the United States earlier than might have been anticipated given the past experience of other countries. Remarkably, the rise in arrears rates happened before the traditional triggers of a macroeconomic downturn and tighter lending standards.

After documenting these aspects of recent developments in the next section, I turn in Section 3 to examining the institutional arrangements in the US housing-finance system that might help explain the housing meltdown in the United States. I argue that differences in the responsiveness of the homebuilding sector, the tax and legal systems, financial regulation and the mortgage market all contributed to the housing meltdown. Many of these 
factors were long-standing features of the US system, but they interacted with the easing in credit conditions to amplify its effect, in ways that were perhaps not anticipated at the time.

The policy implications of these observations are discussed in Section 4. The first of these is that home mortgage markets outside the United States were very unlikely to have been the trigger for a financial crisis. Higher household indebtedness could exacerbate the effects of a macroeconomic downturn sparked by some other shock. But the household sectors in non-US economies were unlikely to have been the initial source of the shock.

The second main policy lesson is that housing markets are inherently prone to price cycles because the supply of housing stock is inherently sticky. Not all price booms are actually driven by speculative bubbles, at least initially, and it could be damaging to policy credibility to treat all such booms as being the result of bubbles. Another aspect of the stickiness of housing supply is that when extra supply does come onto the market, it remains in existence even if demand falls away again. This leads to the third main policy lesson, that housing markets can be vulnerable to the effects of a temporary excessive easing on lending standards for home mortgages. When lending standards ease in a way that is not sustainable, housing demand rises and extra homes are built. The extra supply will result in prices undershooting the earlier equilibrium when lending standards tighten again. Economies with more flexible housing supply, such as the United States, therefore risk having more painful busts even though their boom phases look smaller viewed through the lens of housing prices.

The implication for regulatory policy is that in countries where housing supply is especially flexible, or where tax and other institutional arrangements encourage households to carry more debt than they otherwise would, it becomes even more important to financial stability to ensure that the debt was prudently lent. It may be that these countries should regulate mortgage lending practices even more tightly than countries that lack these features, or at least monitor housing markets especially closely for signs of imbalances.

\section{The Narrative: What Happened Differently in the United States?}

\subsection{The Construction Boom Created Excess Supply}

US housing construction peaked in early 2006. By the end of that year, housing starts had fallen by around $40 \%$. The decline was at that point broadly in line with past downturns in the United States and some other countries, such as Australia or Canada (Figure 1, left-hand panel). Unlike those earlier episodes, however, this time the United States has ended up with an overhang 
of excess supply. This is evidenced by the proportion of vacant homes for sale, especially for houses built since 2000, which is not apparent in the other countries shown. (Figure 1, right-hand panel). In many of those countries, governments and other observers have been concerned about a lack of housing supply. ${ }^{1}$ The ratio of housing construction to GDP might have been lower in the US boom than in some other countries, but it seemed that new supply exceeded underlying housing demand by more. Focusing on this ratio alone can be misleading: demand fundamentals such as income and population growth determine how much construction is sustainable, in order to achieve the desired housing stock.

\section{Figure 1 Housing Construction and Vacant Homes}

(1)Housing Construction as Percent to GDP (2) US Housing Vacancy Rate (Percent) ${ }^{\mathrm{a}}$

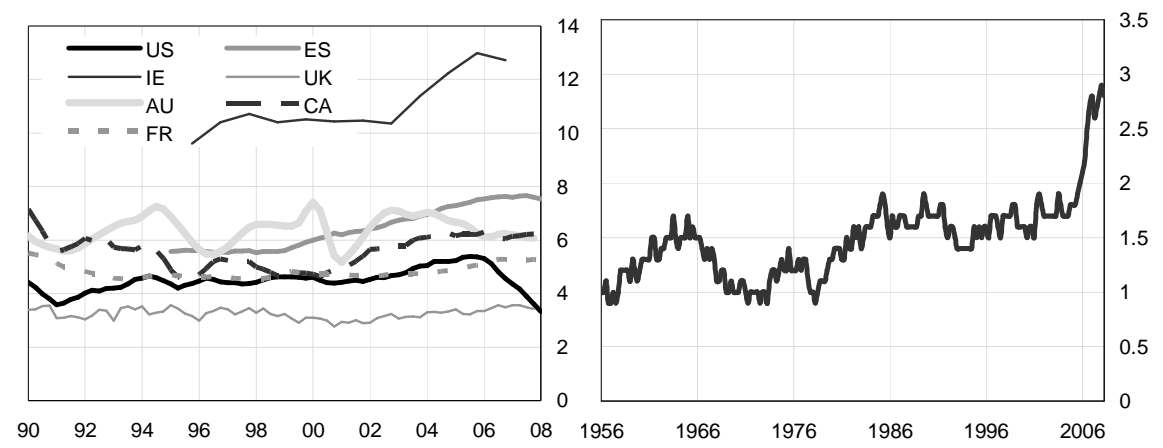

Note: ${ }^{\mathrm{a}}$ Vacancy rate is the number of homes that are vacant and for sale as a percentage of homes that are either owner-occupied or vacant and for sale.

Sources: National Sources, DataStream. US housing vacancies data are available from the Census Bureau, at http://www.census.gov/hhes/www/housing/hvs/hvs.htm and at http://www.census.gov/hhes/www/housing/hvs/qtr108/q108tab3.html disaggregated by construction date.

The standard analysis of housing demand recognizes that it consists of a demand for a certain number of dwellings, and separately for their average quality - the housing services that each provides. Housing construction adjusts the stock over time to match demand (Egebo, Richardson and Lienert 1990). New dwellings are needed to accommodate population growth and to replace older stock that does not match households' quality expectations as incomes rise. So construction of new dwellings should be higher in countries with high population growth and also where income is growing rapidly, since this will boost both household formation rates and the desire to replace the older stock

${ }^{1}$ In the United Kingdom, the government commissioned the Barker Review of Housing Supply (Barker 2004). In Australia, concerns about housing supply and affordability led to inquiries by the Productivity Commission in 2003 (Productivity Commission 2004) and by a Senate Select Committee in 2008. 
that offers a lower level of housing services. Similarly, in countries where household income is growing rapidly, construction can be expected to include high levels of renovation and an increasing average quality of newly built homes.

We can compare the US housing construction boom to those in other countries in light of these factors. Figure 2 shows that between 2001 and 2006, the United States built more new homes than would seem to have been required by the growth in its population. In contrast, countries such as Canada, the United Kingdom and Spain barely managed to build enough homes to keep up with growth in the number of households. Only in Ireland was the gap between growth in the dwelling stock and in the number of households larger than the gap in the United States. The difference in Ireland might partly reflect the dwelling stock catching up to earlier increases in the number of households. Average household size in Ireland fell significantly over the past two decades; it is still above the average in other industrialised countries. The excess addition to the US housing stock cannot be reconciled to demographic fundamentals in this way.

\section{Figure 2 Housing Construction and Demand Fundamentals}
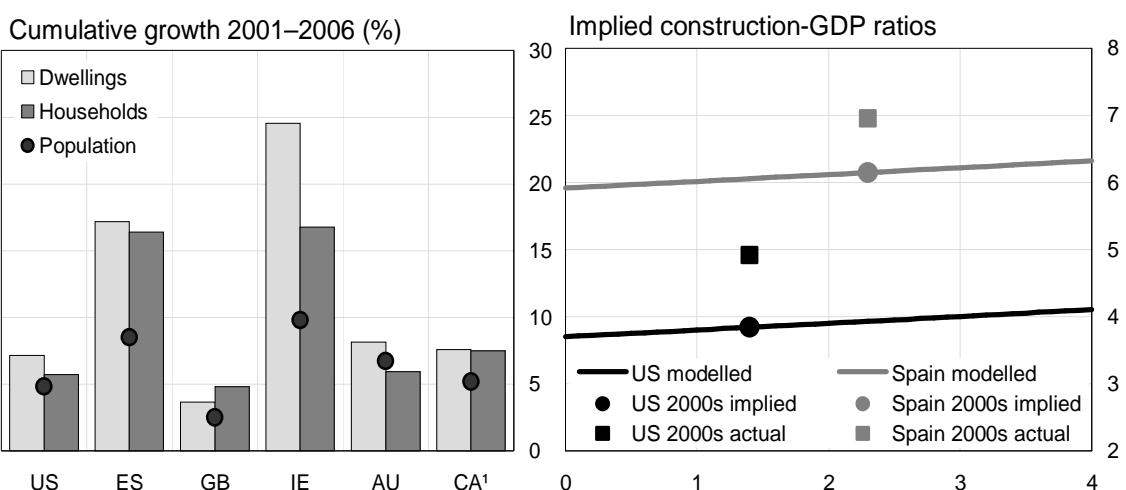

Average Annual Growth in GDP per Capita

Note: ${ }^{\mathrm{a}} \mathrm{US}=$ United States; ES = Spain; GB = Great Britain(Excludes Northern Ireland); $\mathrm{IE}=$ Ireland $; \mathrm{AU}=$ Australia; $\mathrm{CA}=$ Canada. ${ }^{*}$ Dwellings growth for Canada refers to occupied dwellings only.

Sources: National Sources, DataStream. The figures on average household size in Ireland are from the Irish Central Statistics Office, and are available at http://www.cso.ie/census/. The Spanish housing price growth figures referred here are the national index (DataStream code ESHOUPRCF) and national price per square metre (DataStream code ESHOUSE.A), both of which recorded growth of around 2\% over the year to the second quarter of 2008, and a slight fall in the quarter. The regional and city-level prices were obtained directly from the website of the Ministerio de Vivendia. 
The US housing boom also involved substantial renovation of the existing housing stock and an increase in the average quality of (detached) houses that seems large compared with its past relationship with income growth. For example, the median floor space of newly built single-family homes in the United States increased at an average annual rate of around $1.6 \%$ over the period 2000-2006. ${ }^{2}$ This was roughly double the rate seen over the 1990s, when real household income growth had been faster. Moreover, unlike past and current booms elsewhere, the recent US housing boom did not seem to have any impetus from optimism about household income growth. Ireland and Spain have clearly been on convergence paths where a period of rapid growth in incomes could be expected. Optimism about incomes growth (warranted or otherwise) also seems to have been one of the triggers of the booms in the United Kingdom, Australia and the Nordic countries in the late 1980s (Attanasio and Weber, 1994, Drees and Pazarbasiouglu, 1998). No such optimism can be discerned either in the US household surveys or in the recent actual US data.

The excess supply in the United States can be quantified approximately using a simple stock-adjustment relation. Suppose the desired housing stock at time $t$, $H_{t}{ }^{*}$, depends on the population $\left(P O P_{t}\right)$ and the desired housing services per capita, which (in the absence of relative price shifts or any effects from changes in the average household size) will depend on per capita income $\left(Y_{t}\right)$ and the (assumed constant) rate at which housing stock per capita converts into housing services, $\alpha$. The result is the equilibrium relation shown in (1). The change in the desired stock therefore depends on population and income growth, as in (2).

$$
\begin{aligned}
H_{t}^{*} & =\alpha Y_{t} P O P_{t} \\
\Delta H_{t}^{*} & =\alpha \Delta P O P_{t} Y_{t}+\alpha \Delta Y_{t} P O P_{t}
\end{aligned}
$$

A change in the desired stock would not be expected to be satisfied with new construction in a single year; any current deviation between the actual housing stock $\left(H_{t}\right)$ and the desired one $\left(H_{t}^{*}\right)$ would also be only partially met. Actual construction $\Delta H_{t}$ can therefore be written as (3), where $\beta$ and $\gamma$ are partial adjustment factors. The third term on the right-hand side captures the fact that some construction is needed to offset the physical depreciation (at rate $\delta$ ) of the existing housing stock.

$$
\Delta H_{t}=\gamma\left(H_{t-1}^{*}-H_{t-1}\right)+\beta \Delta H_{t}^{*}+\delta H_{t-1}
$$

Dividing through by realGDP $\left(Y_{t} \times P O P_{t}\right)$ givesan equation for the share of(real) construction in GDP (4), which can be regressed on actual data. Since this is an equation capturing adjustments back to long-run equilibrium, we use fourquarter-ended changes of population and income and treat the fraction with

2 US floorspace data are from the US Census Bureau,
http://www.census.gov/const/C25Ann/sftotalmedavgsaft.pdf.


GDP growth in the denominator as a constant, evaluated at its average over the whole sample. We also omit from this simple exercise shorter-run factors such as interest rates and deviations of relative prices from their long-run average. (The symbol $\Delta$ with lower-case variables denotes proportionate changespercentage changes divided by 100-in the corresponding upper-case variable.)

$$
\frac{\Delta H_{t}}{G D P_{t}}=\gamma \alpha \frac{1}{1+\Delta g d p_{t}}+\beta \alpha \Delta \text { oop }_{t}+\beta \alpha \Delta y_{t}+\frac{(\delta-\gamma) H_{t-1}}{G D P_{t}}
$$

To recover the underlying parameters $\alpha, \beta$, and $\gamma$, we require an assumption for $\delta$, which we take from US Census Bureau data on average depreciation rates for the housing stock. This depreciation rate is also used to estimate the housing stock in each period $H_{t}$, using a recursive calculation cumulating actual construction, less depreciation, from a starting value based on Census Bureau housing stock estimates. ${ }^{3}$ The parameters on population and income growth were not forced to be equal,so the partialadjustmentfactors could differ depending on whether the desired stock was changing because of population growth (number of houses) or income growth (average quality of housing).

With these estimated underlying parameters in hand, we can determine how quickly construction catches up to a change in fundamentals on average (estimated $\beta \mathrm{s}$ ), and whether this behavior changed during the recent housing construction boom. Given the housing stock in 2000 and an average population growth of around $1 \%$ per annum over the period 2000-06, the relationship between income growth and the normal share of housing construction in real GDP (estimated over 1972-2000) is as shown by the black line in the righthand panel of Figure 2. Average growth in income per capita over the period 2000-2006 was $1.4 \%$, so the historically typical stock adjustment rate could have been achieved with an annual average ratio of housing construction to GDP of $3.8 \%$, as shown by the black dot on top of the line. The actual average over the period, shown as the black square, was $4.9 \%$. This difference implies significant excess construction compared with historical behavior: indeed, the out-of-sample forecast errors over 2000-06 are large, in contrast to the regression's reasonable in-sample fit.

As a counterfactual exercise, applying the same coefficients to Spain's higher population growth and lower initial housing stock implies an average relationship between income growth and housing construction more like the grey line in the figure. ${ }^{4}$ The grey dot shows the point corresponding to Spain's

\footnotetext{
${ }^{3}$ We (Garcia and Ellis) do not use the Census Bureau estimates for the whole period because they do not line up with the construction data we are modelling, especially around Census dates.

${ }^{4}$ These calculations are moderately sensitive to the assumption about the initial housing stock to GDP ratio. For Spain, this is calculated based on estimates of the housing stock (excluding land) for 2000, taken from Naredo, Carpintero and Marcos (2005). The line would still be above that for the United States unless the housing stock per unit of GDP
} 
actual average income growth over 2000-07 (2.4\%). The actual outcome for the construction-GDP ratio, shown by the grey square, is higher than this, but the gap is smaller than for the United States. It cannot be completely ruled out that some overbuilding has occurred in Spain, but clearly, most of the difference between the two countries' ratios of housing construction to GDP can be explained by different fundamentals.

This conclusion is strengthened by the fact that the counterfactual exercise assumes that construction fundamentals in Spain are explained by the same model as in the United States. This assumption might not be realistic given the range of other fundamentals implying that Spain's equilibrium housing stock has increased in recent years. These include: the permanent down-shift in nominal interest rates (and increase in borrowing capacity) associated with euro entry; the faster decline in household sizes; and the importance of nonresidents' second homes in Spain compared with the United States.

Spain has also entered into a sharp housing downturn recently, but the effect on housing prices has been quite drawn out. Four years after the peak rate of price growth was recorded, the level of nationwide housing prices finally peaked in the second quarter of 2008. Despite a severe recession, housing prices only fell by around 10\% in the following year (to Q1:2009), compared with a peak-to-trough move of more than $30 \%$ in the United States, according to some measures. The conclusion from this and from the simple exercise shown in Figure 2 therefore has to be that the downturn in housing construction in Spain started from a position of less (or even no) oversupply, in contrast to the US situation.

\subsection{Lending Standards Seem to Have Eased More in the United States}

Mortgage lending standards eased in many countries in recent years, but the process seems to have gone further in the United States. Standards are difficult to measure because different aspects need not all move together (Gorton 2008, Bhardwaj and Sengupta 2008), but the observed increase in early payment defaults in the United States (but not elsewhere) provides direct evidence that it occurred (Kiff and Mills 2007); Gerardi, Lehnert, Sherlund and Willen (2008) provide additional detail on the easing in lending standards.

In addition, that US mortgage lending standards eased more than elsewhere is evidenced by a number of specific products and developments seen in the United States but not in other countries that experienced housing price booms over this period, or at least not to anywhere near the same extent. Only in the United States were negative amortisation mortgages available, along with "silent seconds" (undisclosed second mortgages) and downpayment assistance charities, often funded by vendors. Likewise, only in the United States did

was well above the US ratio, which it almost certainly is not. 
certain markers of fraudulent behaviour, such as appraisal fraud, the use of straw buyers, and the "renting" of credit scores, become so widespread.

Two developments seem to have spurred the easing in US standards. First, a range of legislative and policy changes had been made to encourage the development of a non-conforming (Alt-A and subprime) lending sector, lying outside the model defined by the government-sponsored enterprises (GSEs, Fannie Mae and Freddie Mac). Part of the motivation for this was a desire to ensure that home ownership was accessible to households who had historically been under-served by mortgage lenders (Gramlich 2007). In addition, the administration had wanted to reduce the GSEs' domination of the mortgage market. Following problems with accounting and governance at both institutions, the GSEs' capacity to expand lending was capped by new regulatory limits on their activities (Kiff and Mills 2007, Blundell-Wignall and Atkinson 2008) ${ }^{5}$

Second, origination volumes had fallen following the end of the refinancing wave of 2003. Lenders therefore faced a substantial reduction in fee income, with implications for the size of the entire industry. The low rates on long-term fixed-rate mortgages available in 2003 had allowed borrowers to cut their interest rate significantly, by one-fifth on average for loans refinanced with Freddie Mac, for example. Total originations peaked at around \$4 trillion, with MBS issuance not much less than that (Figure 3, left-hand panel). ${ }^{6}$ As a result, around half the outstanding mortgage stock turned over in that year, either through moving or refinancing. According to the Federal Reserve's 2004 Survey of Consumer Finances, $45 \%$ of households with a first mortgage had refinanced within the previous three years (Bucks, Kennickell and Moore 2006).

Rather than see the industry shrink, lenders responded by easing underwriting standards across several dimensions. The first of these was that nonconforming mortgages did indeed gain market share. Subprime loan origination grew particularly strongly, but the Alt-A category did as well (Figure 3). Much of the expansion occurred in lending originated by specialist lenders. This shift included entry into the market by major investment banks via newly acquired mortgage-lending subsidiaries. Even if lenders within each category had not eased standards, the result would have been that more of the

\footnotetext{
${ }^{5}$ Contrary to some media commentary, there is no evidence that the Community Reinvestment Act was responsible for encouraging the subprime lending boom and subsequent housing bust. This Act only applies to depositories, and did not cover most of the important subprime lenders. Depositories showed a lesser tendency to write subprime loans than lenders not subject to the Act (Yellen 2008).

${ }^{6}$ Freddie Mac's refinancing data are available from their statistical release page: http://www.freddiemac.com/news/finance/data.html. The figure for total mortgage originations in 2003, also on this page, was taken from the trade publication Inside Mortgage Finance.
} 
US mortgage book contained features that raised delinquency and default rates. As documented by Quercia, Stegman and Davis (2007), even in the late 1990s, loans originated by designated subprime lenders were much more likely than prime lending to include features that boost default rates, such as prepayment penalties and balloon payments.

\section{Figure 3 US MBS Issuance and Subprime Lending Standards}

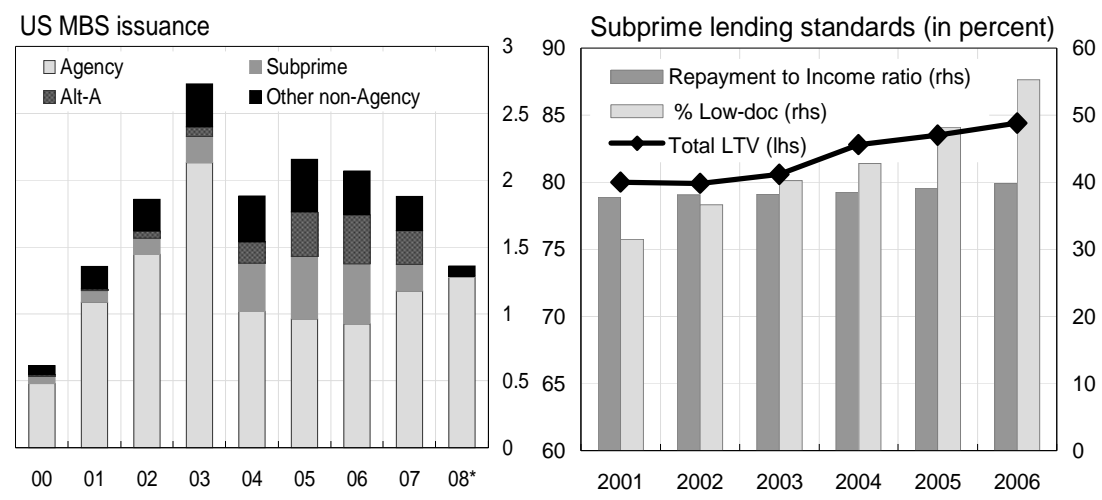

In trillions of US dollars; Figure for 2008 is for the first quarter, annualised.

Sources: Left Panel - UBS; Right Panel - Reproduced from Table 1 in Demyanyk and Van Hemert (2007).

The easing in US mortgage lending standards went beyond a shift amongst lenders with different business models. An array of statistical evidence and legal findings shows that underwriting standards of individual lenders eased as well. First, and perhaps most importantly, requirements for documentation of income and assets became progressively laxer. Instead of assessing borrowers' abilities to service their loans, lenders ended up focusing on collateral values, in effect betting on rising housing prices (Gorton (2008) makes a similar point).

Figure 3 (right-hand panel) shows that amongst securitised subprime loans, the share of 2001 originations that were "low-doc" stood at around $30 \%$. For the 2006 cohort, the share increased to more than half (Demyanyk and Van Hemert 2007). Amongst Alt-A pools of loans, the picture is even starker: only around $40 \%$ of fixed-rate mortgages and one-quarter of Alt-A adjustable-rate mortgages (ARMs) had full documentation as at May $2008^{7}$. While low-doc (self-certified) mortgages are available in the United Kingdom and Australia, they have been much more prevalent in the United States. In 2005, lowdocumentation loans represented around $10 \%$ of new and $5 \%$ of outstanding

${ }^{7}$ The figures for full documentation on Alt-A loans comes from the Federal Reserve of New York's analysis of a $1 \%$ sample of LoanPerformance data, available at http://newyorkfed.org/regional/US_May.xls, accessed 3 July 2008. 
mortgages in Australia (RBA 2005b), compared with more than one quarter of US mortgages originated in recent years, as the above-mentioned figures imply.

Second, the sustained period of low US policy rates also made ARMs more attractive to borrowers relative to fixed-rate loans in the short term. There was a substantial shift of the US mortgage book into ARMs, in contrast to the pattern of the previous several decades. Some ARM products were rendered even more attractive to borrowers by their low introductory "teaser" interest rates.

Comprehensive information on the size of rate discounts is not available, but it seems that they were deeper in the United States than elsewhere, whether currently or in earlier periods of increased competition. For example, new mortgage lenders funding themselves through securitisation entered the Australian mortgage market in the mid-1990s, increasing competition. The "honeymoon" teaser interest rates they offered were only about $0.5-1.5$ percentage points below the standard variable home loan rates to which they would reset (RBA 1999c, page 30). Data published by the Bank of England suggest that in the United Kingdom, discounted rates are also only a little below standard variable interest rates. By contrast, teaser rates on US subprime loans tended to be around 3-4 percentage points below the rate to which the mortgage would reset (given unchanged market rates) and the gap was at least as large for prime ARMs. There is little evidence that resets were a major factor in the initial increase in delinquencies and foreclosures: the largest wave of subprime resets occurred in 2008 or later (Cagan 2007, Foote, Gerardi, Goette and Willen 2008a). Nonetheless, the larger gap between teaser and reset rates provides indirect evidence that US lenders eased standards more than lenders elsewhere.

A third element of the US easing in credit standards was the increased use of second mortgages, whether at purchase (a "piggyback") or subsequently (usually a home equity line of credit). The prevalence of home equity loans had already increased from less than 5\% in 2001 to $8.6 \%$ in 2004, according to the Federal Reserve's Survey of Consumer Finances. In subsequent years, piggyback loans became increasingly common (Avery, Brevoort and Canner 2007, GAO 2007), in part because they were more attractive than paying for mortgage insurance (see Section 3.2). Many US households seem to have been able to obtain $100 \%$ financing in this way, which enabled higher overall LTV ratios at origination. In other countries, explicit (insured) 100\% financing is normally necessary.

In addition, Ashcraft and Schuermann (2008) cite LoanPerformance data showing that many of these piggyback loans were not disclosed to the originator of the first mortgage. These so-called "silent second liens" were very rare in the 1990s, accounting for much less than $1 \%$ of subprime and AltA loans originated in 1999. But by 2006, more than one-quarter of securitised 
subprime and nearly $40 \%$ of securitised Alt-A first mortgages had a silent second. The associated first mortgages must therefore have been mispriced, because the originator did not know the borrower's true LTV ratio, and thus their true risk. There is no evidence that silent seconds (as opposed to second mortgages that the lender knows about) exist in any significant numbers in other countries.

A fourth, related, element was that initial LTV ratios on new mortgages increased substantially, and explicit $100 \%$ financing became much more common. Cagan (2007) estimates that around 18\% of mortgages originated in 2006 were in negative equity by the end of that year, suggesting an initial LTV ratio at or close to $100 \%$. This development was not unique to the United States: mortgages for $100 \%$ or more of valuation also became more prevalent in the United Kingdom and the Netherlands in recent years, for example. But even in these countries, borrowers with initially high LTV ratios remained a small minority of the total during the first half of this decade (Benito 2006). Moreover, these were countries where high-LTV ratio financing had been available for many years. As Tsatsaronis and Zhu (2004) identify, the US mortgage system had previously tended to lend at more conservative LTV ratios and for fixed rates, so this constituted a greater net easing in standards there.

Effective LTV ratios also rose because many US buyers were not using their own funds for the downpayment they did make. Third-party contributions to fund downpayments seem to have become widespread, especially for more marginal borrowers. Downpayment assistance eases the credit constraint represented by downpayment requirements; contributions by friends and family have long been used for this purpose (Mayer and Engelhardt 1996). More recently, though, sellers started providing funds, sometimes channelled via charities, in lieu of an actual downpayment. This gave rise to concerns that prices were being inflated by the amount of the assistance, and that the credit quality of the mortgages was less than those where the downpayment came from the borrower's own funds (Concentrance Consulting Group 2005). In any case, if funds for downpayments are available from sources other than the buyers' own savings, their incentives to negotiate with the seller to reduce an inflated price are substantially lessened. The actual transacted price could therefore have been inflated, giving lenders false comfort about the true loanto-valuation ratio. ${ }^{8}$

\footnotetext{
${ }^{8}$ Seller-financed down payments are not a fringe product in the US mortgage market, but are essentially unheard of elsewhere. They have grown to one-third of the Federal Housing Administration's (FHA) insured portfolio, and are three times more likely to go into foreclosure than other FHA mortgages (Montgomery 2008). In late 2007, the Federal Housing Administration (FHA) tried to ban the use of such assistance from seller-financed charities for FHA-insured mortgages. After this ban was blocked by a court injunction in early 2008, the practice was finally banned by the Housing Rescue and Foreclosure Prevention Act of 2008.
} 
Finally, interest-only and negative amortisation loans became more prevalent in the United States in recent years. According to LoanPerformance data, $33.7 \%$ of securitised purchase loans originated in the first quarter of 2007 were interest-only and a further $7.3 \%$ were negative-amortisation. Thus as well as initial LTV ratios being higher than before, they stayed high on an ongoing basis. Again, these loan types seem to have been more common in the United States than elsewhere: in fact, there does not seem to be any evidence that negative amortisation products exist at all in any of the peer group of countries considered here. As discussed below, one consequence of this is that US households were more likely than those in other countries to end up in negative equity as housing prices started to fall.

Within the subprime market, at least, some of the easing in standards in the dimensions of LTV ratios, documentation standards and amortisation patterns was at least partly compensated for by requiring that borrowers of these loans have higher credit (FICO) scores than average (Bhardwaj and Sengupta 2008). The result of this trade-off was probably to shift the overall subprime mortgage loan book to a state of being more resilient to idiosyncratic income shocks (as captured by FICO scores), but less so in the face of lower housing prices. Higher initial LTVs and non-amortising loans imply that borrowers would be more likely to end up in negative equity if housing prices fall, and thus less able to sell or refinance their home rather than default (Ellis 2008). Falling housing prices were clearly implicated in many of the early defaults on US mortgages recently (Haughwout, Peach and Tracy 2008). The trade-off in lending standards might have seemed reasonable given credit risk assessments using historical data that only covered periods of rising prices. Allowing for the risk of falling housing prices, though, this shift should be interpreted as a net easing even within the subprime market.

\subsubsection{Negative Equity Became Unusually Widespread}

Housing prices increased rapidly in the United States during the boom phase by around two-thirds over the period 2000-06 - but mortgage debt more than doubled. The average gearing on the housing stock rose steadily, reaching around $45 \%$ even before prices started to fall; this is almost double the ratio in Australia, for example. Since around 30\% of US homeowners own their homes outright (Bucks et al. 2006), a sizeable minority of households must have had very little equity in their homes, even at the price peak.

Current LTV ratios for mortgages that were not originated recently can often only be calculated approximately. Houses that are not currently on the market will not have a recent market price to refer to; appraisals might also contain some estimation error. No comprehensive, official data sources exist on current LTV ratios for existing borrowers. One private sector estimate nonetheless suggested that more than $10 \%$ of the US single-family housing stock (around 7\% of all households) were already in negative equity in early 
2008. Subsequent estimates for early 2009 were as high as one in six. Cagan's (2007) estimates suggest that around $5 \%$ of loans made in the boom period of the early 2000s were already in negative equity at the end of 2006, though the figure for older loans was lower. These estimates are much higher than the available corresponding figures in other countries, or even the peak proportions reached in some other countries' past housing busts. For example, in the United Kingdom, recent Bank of England estimates derived from survey data imply that less than $5 \%$ of households with mortgages (and an even smaller proportion of all households) would end up in negative equity, even if housing prices were to fall by $20 \%$ or more (Bean 2008).

The unusual prevalence of negative equity in the United States has been driven by several factors. Firstly, because of the pattern of frequent refinancing, the stock of outstanding mortgages is quite young and borrowers have had little time to pay down principal. Even with a normal amortising mortgage, the principal is only paid down slowly in the first few years. Secondly, as was noted above, interest-only and negative amortisation loans seem to have been more prevalent in the United States than elsewhere in recent years. Their popularity has meant that more households could have higher ongoing LTV ratios for a given starting LTV ratio. They were therefore more likely to fall into negative equity if house prices fell.

Negative amortisation products - commonly known as Option ARMs or PayOption ARMs - are particularly prone to sending borrowers into negative equity if prices stabilise or fall. Borrowers of this type of mortgage can nominate a payment which does not even cover the interest. Any shortfall would be capitalised into the loan balance, up to a pre-specified limit relative to the original loan size. At that point, the required payment would be recalculated ("recast") to be the amount needed to fully amortise the loan over the remaining term. On top of the payment shock effects of these recasts, negative amortisation products imply a greater risk of default because they can end up in negative equity even if housing prices do not fall. All that is required is that housing prices rise by less than the rate of interest capitalised during the negative amortisation period.

Another factor that could have driven the apparently high prevalence of negative equity was that the boom-bust cycle was concentrated in a few areas. The incidence of negative equity depends on the number of borrowers in the tail of the distribution where the fall in prices exceeds the percentage of the home's value representing their home equity at the point that prices peaked. A small price fall on average will result in more borrowers falling into negative equity if the distribution of price falls includes a tail of extremely large falls, than if the price fall is more evenly distributed. Thus the national price indices probably understate the percentage of households with negative equity in those areas. The overall incidence might therefore be greater than simulations using national data imply. Again, this seems to have been a particular issue for the 
United States. As an indicator of this, the coefficient of variation of house price growth rates in the United States across states or cities more than doubled between 2002 and 2006. In contrast, those for Australia, Spain and Britain were not only somewhat smaller during the earlier parts of their booms, as would be expected for the less diverse regions in smaller economies: they also did not rise as much, if at all, as their booms progressed. ${ }^{9,10}$

\subsection{Arrears Rates Deteriorated Before the Economy Did}

In the current US housing downturn, mortgage arrears started rising before the economy turned down and before credit tightened. As the right-hand panel of Figure 4 shows, arrears rates started to rise rapidly, well before unemployment did. Even the arrears rate on prime mortgages increased by one-quarter between its trough in early 2005 and mid-2007, despite a decline in unemployment over this period. By the end of 2007, arrears rates were much higher than in the previous recession. All this occurred well before credit standards were tightened. The tightening in credit, especially the reduced availability of subprime and Alt-A loans, was a response to increasing delinquencies and defaults, not the initial impetus to them. This was exactly the opposite of the sequence of events in other countries over the current cycle.

Arrears rates also responded unusually swiftly to the fall in housing prices. After drifting up fairly gently since the end of 2004, both the Federal Reserve and Mortgage Bankers Association measures of arrears experienced points of inflection in the third quarter of 2006. This was the same period that the CaseShiller national house price index recorded its first quarterly fall of the current episode; the turning point in the serious (90-plus days) delinquency rate shown in Figure 5 was two quarters later.

These developments contrast with the pattern seen in previous housing busts. The Canada and United Kingdom panels of Figures 4 and 5 show how this played out in the early 1990s busts in the United Kingdom and Canada. In the United Kingdom, house prices peaked in mid-1989, and there was a slight rise in arrears rates in the following year. But the large cycle in delinquencies seems to have coincided with the unemployment rate. Likewise in Canada, arrears rates started rising in advance of unemployment, but the large upswing seemed to be just as much driven by rising unemployment as falling housing

\footnotetext{
${ }^{9}$ In Canada, the coefficient of variation was lower than that in the United States for most of the past decade, but rose markedly from around mid-2006, as the price boom became skewed to the mining-dominated provinces of Alberta and Saskatchewan.

${ }^{10}$ The calculations of the coefficients of variation of housing price growth used OFHEO data for the United States, Department of Communities and Local Government regional data for the for the United Kingdom excluding Northern Ireland (via DataStream), Australian Bureau of Statistics house price indices (Cat. No. 6416.0) for Australia, Statistics Canada house price indices (via DataStream) for Canada, and the above-mentioned Ministerio de Vivendia data for Spain.
} 
prices. The United States did not experience a national housing downturn in this period, but several regions did. Even there, it took a macroeconomic weakening before arrears rates started to rise significantly (Rosengren 2008). ${ }^{11}$

\section{Figure 4 Arrears Rates and Unemployment}
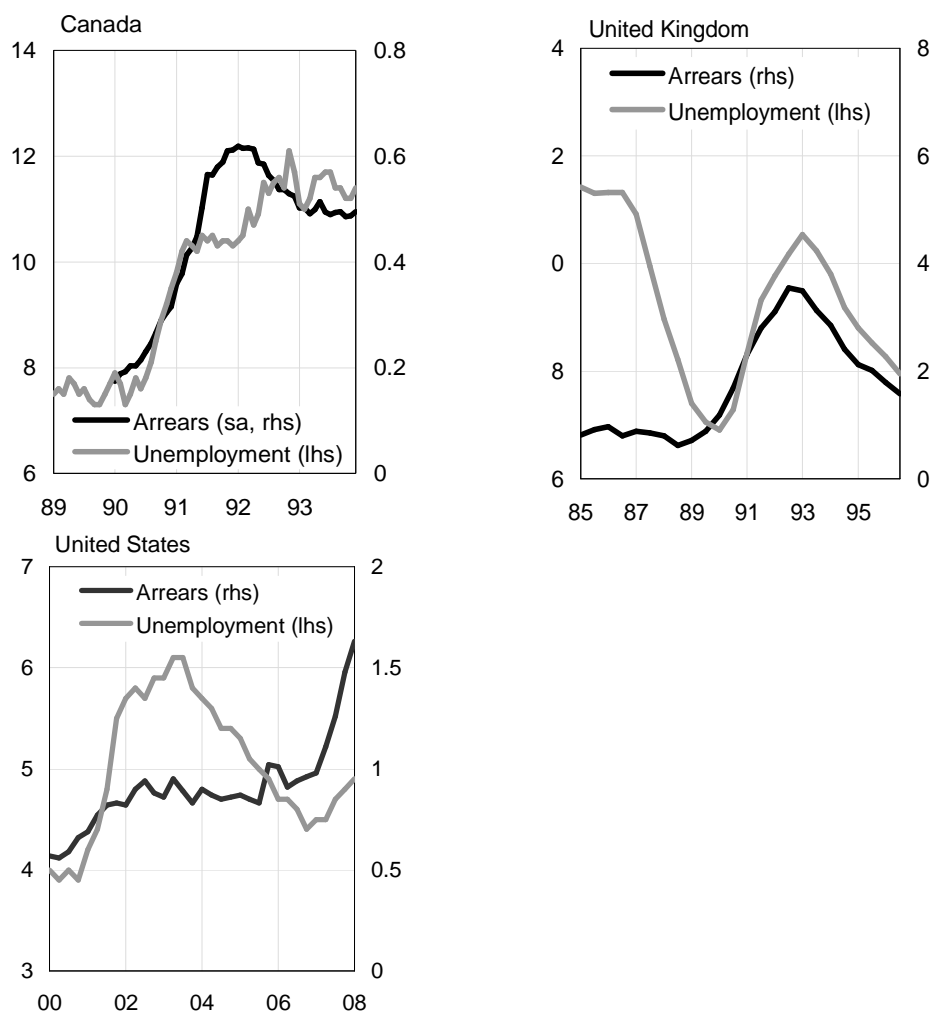

Note: Arrears rates for the United Kingdom and Canada are for loans at least 3 months in arrears. For the United States, rate is the "serious delinquency" rate (90+ days in arrears or in foreclosure).

Sources: Council of Mortgage Lenders, Canadian Banker Association, Mortgage Bankers Association, National Sources via DataStream

The rapid increase in US arrears rates, absent a macroeconomic downturn, also contrasts with more recent experience elsewhere. For example, both the United Kingdom and Australia experienced mid-cycle slowdowns and even falls in

\footnotetext{
${ }^{11}$ A similar pattern also seems to have applied in the banking crises in the Nordic countries around the same time, although without time series for arrears rates on residential mortgages, it is difficult to be precise about the timing. From the pattern of credit losses, however, it is clear that households were not the first or most important class of defaulters in the Nordic banking crises (Drees and Pazarbasiouglu 1998).
} 


\section{The US Housing Meltdown}

housing prices in the mid 2000s, as interest rates rose. Arrears rates increased somewhat during this period, but drifted down again after several quarters (RBA 2007a). Neither country saw an increased tendency for early-stage delinquencies to convert to serious $(90+$ days) delinquency and ultimate default, suggesting that these were borrowers with temporary payment difficulties. Likewise, housing prices started to fall in Ireland early in 2007, but according to the central bank's end-2007 financial stability report, there was as yet no sign of increasing arrears rates. More recently, arrears rates in the United Kingdom and Spain only started to rise significantly once unemployment did.

\section{Figure 5 Arrears Rates and House Prices}
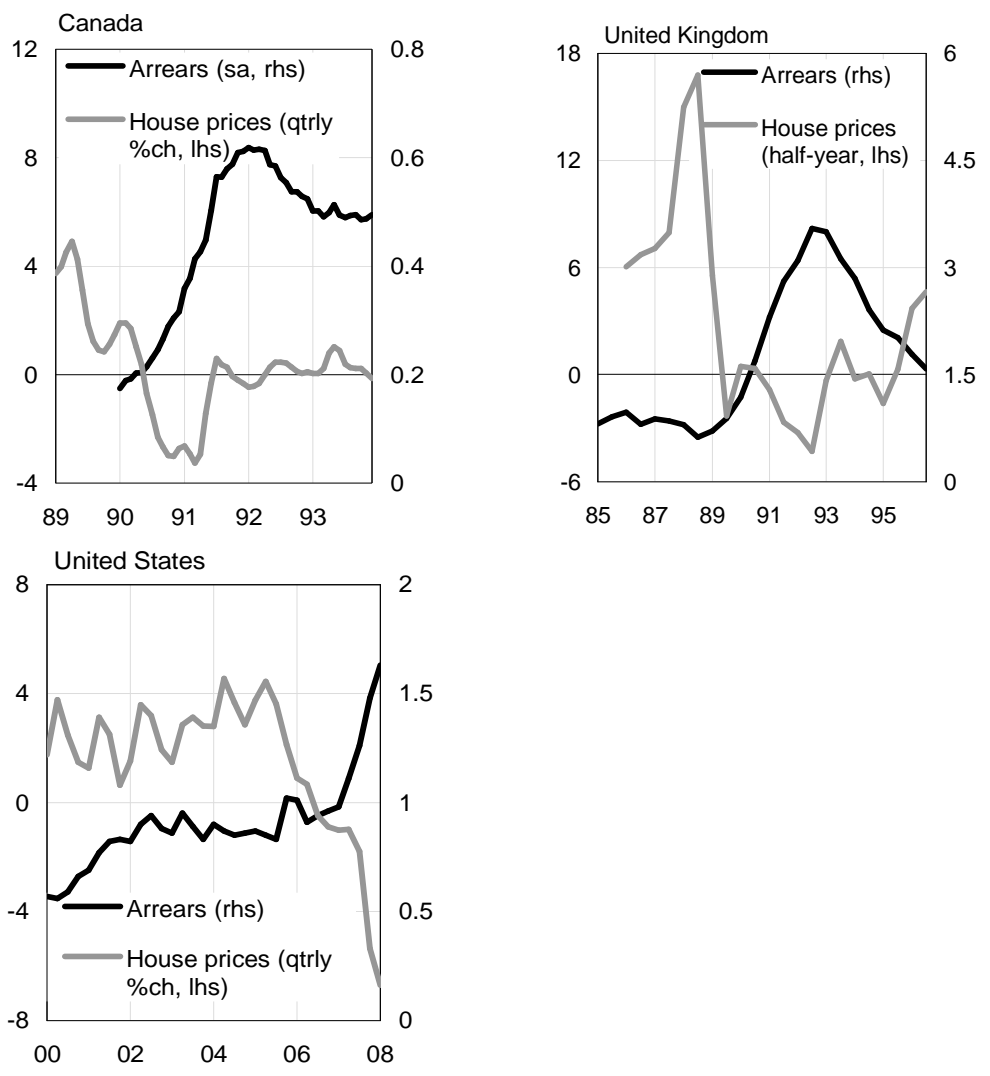

See Notes to Figure 4.

Compared with the more recent US bust, these other episodes seem to have been driven by a different mix of the two motivations for mortgage delinquency and default emphasised in the literature. The ability-to-pay model emphasises the affordability of the repayment, and individual income-related factors such as income, income variability and employment (Barth and Yezer, 
1983, Deng, Quigley, Van Order and Mac, 1996, Diaz-Serrano, 2005). Households default on their mortgages because they lose their jobs, get divorced, or incur large medical bills (Bernanke 2008). Rising interest rates (and thus required mortgage repayments) could add to the effect. These are mainly the idiosyncratic risks of individual personal tragedy, although macroeconomic downturns would also increase delinquencies and defaults as unemployment rises, especially in countries with less of a social safety net. The high level of delinquencies and foreclosures in "rust-belt" states such as Ohio and Michigan should be seen in this context.

A competing model, the equity model of default, treats the choice to default as a put option. It depicts borrowers as defaulting rationally when they are in negative equity (Jackson and Kaserman 1980, Epperson, Kau, Keenan and Muller 1985, Foster and Van Order 1985). The concerns about "walkaways" are based on an assumption that this model describes household behaviour, or may increasingly come to do so.

The full story is probably a more nuanced combination of these factors. Empirical research has generally found that borrowers default far less often than the pure option-theoretic model would predict (Vandell and Thibodeau 1985, Vandell 1995, Foote, Gerardi and Willen 2008b). Some research emphasizes the role of trigger events - including changes in the ability to pay in determining the timing of borrowers' decisions on whether to default (Kau and Keenan 1995, Duygan and Grant 2006).

Even if households only default after experiencing a negative income shock, arrears rates and defaults should still be expected to increase as housing prices fall. As housing prices rise, individual borrowers in financial difficulty can sell their homes and clear their debt without defaulting; for example, arrears rates rose in the New England region during the 2001 US recession, but foreclosures did not, because prices were rising (Foote et al. 2008a). If housing prices are falling, however, borrowers' equity cushions diminish.

They are then more likely to spend some time in arrears after an income shock, because they cannot resolve the situation by selling quickly. Arrears and default rates can therefore start to rise even when unemployment is low, without borrowers seeing this as "walking away".

To disentangle the relative importance of ability-to-pay variables and housing prices, Table 1 presents the results from simple regression models of aggregate mortgage arrears rates, for Canada, Spain and the United States. ${ }^{12,13}$ By

\footnotetext{
${ }^{12}$ The semi-annual frequency of UK arrears data prevented its inclusion. Alternative specifications including the level or change in mortgage interest rates were not more successful than the ones presented in the table. Coefficients on interest rates were generally insignificant. In the US results the few significant coefficients were negative, which suggests that it is not picking up the intended effect of the payment shock of
} 
focusing on arrears rates, the emphasis is on possible differences in borrower behavior, rather than that of lenders. Foreclosures are a joint outcome of the borrowers' defaults and the lenders' decisions to enforce their claim on the collateral, which is in turn affected by the legal system (see Section 3.3 below). Given the increased US market share of subprime lenders with collateraloriented business models, it would not be surprising if foreclosures increased relative to arrears rates. ${ }^{14}$

For Canada and Spain, the results are as expected: arrears rates rise when housing prices fall (negative coefficient on housing price growth) and when unemployment is higher. In Spain, the change in the unemployment rate seems to be at least as important as the level; the recent increase in unemployment is more than sufficient to explain the increase in arrears since mid 2007. Falls in housing prices alone were not significant in the regression for Spain, while in Canada, it seems that increases in housing prices reduced arrears rates more than price falls raised them. Canada experienced a period of falling housing prices in the early 1990s (Figure 5), so if a special role for price falls was to be found in past data, it would be here.

The results for the United States using the OFHEO measure of house prices are also broadly consistent with the predictions from theory. There is a (shortlived) negative effect from housing price growth, while higher unemployment raises arrears rates. All of these coefficients are highly significant, although the fit is poor, and the model completely fails to capture the recent run-up in arrears. There was no special role for housing price falls, though this is most likely because so few falls have been recorded in this series, even on a quarterly basis, prior to the current bust.

\footnotetext{
higher interest rates leading to higher arrears rates. Including interest rates as an explanator did not materially affect the coefficients on other variables. The interest rates used in these alternative econometric specifications were typical mortgage or retail lending rates collected by central banks or other authorities and either republished by DataStream or compiled by the BIS. For Canada, these were the 1-year and 5-year mortgage rates charged by chartered banks; for Spain, the prime lending rate. For the United States, the 30-year fixed conforming mortgage rate published by the Federal Reserve was used for the OFHEO regression, while the average effective mortgage rate published by the Federal Housing Finance Board was used for the Case- Shiller regressions. This difference reflected the longer time series available for conforming mortgage rates, and that they are a better match to the population of transactions used in the compilation of the OFHEO index. These results are available from the author.

${ }^{13}$ The value of doubtful housing loans in Spain is published by the Banco d'España on their web site at http://www.bde.es/infoest/sindie.htm. Note that this definition is somewhat broader than the arrears rates shown for other countries, as it can include loans where repayment is considered doubtful even if not currently in arrears. The same series is used in the econometrics reported in Table 1.

${ }^{14}$ Non-bank and non-conforming lenders also seem increasingly keen to seek repossession in Australia and the United Kingdom of late (RBA 2007a).
} 
Table 1 Results of Various Regression Models of Mortgage Arrears Rates

\begin{tabular}{|c|c|c|c|c|c|}
\hline Country & Canada & Spain & $\begin{array}{c}\text { US } \\
\text { (OFHEO) }\end{array}$ & $\begin{array}{c}\text { US } \\
\text { (Case-Shiller) }\end{array}$ & $\begin{array}{c}\text { US } \\
\text { (Case-Shiller) }\end{array}$ \\
\hline Sample & $\begin{array}{l}\text { 1992:Q1- } \\
\text { 2008:Q1 }\end{array}$ & $\begin{array}{l}\text { 1992:Q1- } \\
\text { 2008:Q1 }\end{array}$ & $\begin{array}{l}\text { 1975:Q1- } \\
\text { 2008:Q1 }\end{array}$ & $\begin{array}{l}\text { 1989:Q1- } \\
\text { 2004:Q1 }\end{array}$ & $\begin{array}{l}\text { 1989:Q1- } \\
\text { 2008:Q1 }\end{array}$ \\
\hline HP Growth & -0.016 & -0.074 & -0.065 & - & - \\
\hline $\begin{array}{l}\text { HP Growth } \\
\text { (Lagged) }\end{array}$ & -0.017 & - & 0.068 & 0.021 & 0.017 \\
\hline HP Falls & 0.011 & - & - & $0.028 \dagger$ & -0.227 \\
\hline $\begin{array}{l}\text { HP Falls } \\
\text { (Lagged) }\end{array}$ & 0.005 & - & - & - & - \\
\hline Unemployment & - & 0.721 & - & 0.419 & 0.351 \\
\hline $\begin{array}{l}\text { Unemployment } \\
\text { (Lagged) }\end{array}$ & 0.008 & -0.509 & 0.155 & -0.397 & -0.410 \\
\hline Constant & 0.442 & $-0.005 \dagger$ & 0.038 & 0.043 & 0.048 \\
\hline R-bar-squared & 0.901 & 0.886 & 0.201 & 0.749 & 0.725 \\
\hline Durbin-Watson & 0.100 & 0.208 & 0.227 & 1.151 & 1.101 \\
\hline
\end{tabular}

Note: Housing price growth calculated as year-ended percentage changes; house prices falls are the (negative) quarterly percentage change in prices when a fall occurred, and zero otherwise. In both cases, "lagged" refers to growth over the year (quarter for falls) ending one year previously. For unemployment, "lagged" refers to the unemployment rate one year previously, except for Canada (nine months previously). All coefficients are significant at the $1 \%$ level at worst, using Newey-West adjusted standard errors, except where marked with a dagger ( $\dagger$, not significant even at the $10 \%$ level).

Sources: Canadian Bankers' Association, Banco de España, DataStream.

Using the Case-Shiller data over a necessarily shorter time period provides a stark contrast to the results for the other countries. The main point can be seen by contrasting the fourth column, where the data sample for the United States ends in 2004, with the fifth, where the whole sample up to the first quarter of 2008 is used. Prior to 2004, the change in the unemployment rate was the strongest predictor of arrears rates, as implied by the ability-to-pay view of mortgage delinquency. Housing price falls had no statistically significant role in the regression, and the coefficient on house price growth was significant and positive.

Adding in the last four years of data results is a completely different story. The role of unemployment diminishes, and the coefficient on housing prices also falls marginally. The coefficient on housing price falls jumps up substantially, however, and becomes highly significant. While this equation's in-sample fit is good, and it manages to capture the upswing in the arrears rate, this only emphasises how sensitive to price falls US households became in the recent 
period. ${ }^{15}$ Out-of-sample forecasts from the model estimated up to 2004 would not have predicted any increase in arrears rates at all, even when the sharp fall in housing prices was allowed for.

Controlling for some measure of ex ante credit quality (e.g. average initial LTV or share of low-doc loans) might have helped disentangle whether this change in the reduced-form relationship between arrears and housing prices could be attributed to observable credit quality. Were such a variable available, a positive coefficient (or a negative one on that variable interacted with housing price falls) would be evidence in favour of the contention that the easing in US mortgage lending standards contributed to the rise in arrears rates seen in the current episode. No such aggregate time series variable exists for the United States or any other country, however, and any series constructed from securitisation data (e.g. the LoanPerformance data in Figure 3) will not go back far enough.

These aggregate regressions might be crude, but they still tell a similar story to the recent work using loan-level data. Demyanyk and Van Hemert (2007) found that arrears rates and defaults were much higher for subprime loans originated in recent years than would have been predicted from their borrower and loan characteristics and the behaviour of subprime loans originated earlier in the decade. Credit quality declined progressively through the decade in all categories of subprime loan. The deterioration only became obvious, however, once housing price growth slowed and borrowers could no longer refinance or sell their way out of trouble.

As well as overall arrears rates rising rapidly once housing prices began to fall, the proportion of loans in serious delinquency - at least 90 days in arrears or in foreclosure - rose even faster, accounting for a much larger share of total delinquencies than usual. This is another data point suggesting that US households have become unusually sensitive to housing price falls, relative to households in other countries, and perhaps to past US experience. If the rise in delinquencies were instead mainly driven by worse income shocks, a larger fraction of borrowers in short-term arrears would be expected to self-cure and get back on schedule. Now that the US labour market has weakened significantly, arrears rates will probably rise further. In many respects, though, this would be a less surprising phenomenon, much more in keeping with past behaviour and with outcomes in other countries.

\subsubsection{An Aside: It Was Not Just Subprime}

As the history books are written, the current financial crisis will inevitably be labeled the "subprime crisis". Yet to focus on the subprime sector to the

\footnotetext{
${ }^{15}$ Another way of showing this changing behaviour is that in the period 1989-2000, arrears rates and Case-Shiller house price growth did not Granger-cause one another, but over 1999-2008, both did.
} 
exclusion of all others is in many ways to misdiagnose the problem. Part of the confusion lies with the definition of subprime (Mayer and Pence 2008). In much of the media commentary, the description has been applied to the borrower, signifying a low-income borrower, or one with an impaired credit record. At other times, it is used to describe loans with risky features such as limited documentation. Studies of securitisation data (Ashcraft and Schuermann 2008, for example) labels loans as subprime if the issuer labeled the MBS as such. Other empirical analysis (Dell'Ariccia, Igan and Laeven 2008, Foote et al. 2008a, for example) uses the definition provided by the Department of Housing and Urban Development (HUD): subprime mortgages are those originated by subprime lenders, defined in turn as lenders meeting criteria unrelated to their customers' FICO scores, though these are definitely correlated. This might help explain why so many "subprime" borrowers were previously and subsequently able to qualify for a "prime" loan (Brooks and Simon 2007). Many properties purchased with prime loans were subsequently refinanced with a subprime loan, and only then went into foreclosure (Foote et al. 2008a).

The absolute level and increase in arrears rates were clearly greater in the subprime segment, however defined. That subprime loans experienced such high rates of arrears and foreclosures was already apparent in much earlier cohorts. For example, around $12 \%$ of subprime refinance loans originated in the late 1990s ended in the loss of the home within five years (Quercia et al. 2007). ${ }^{16}$ The surprise element of the recent increase in arrears does seem to have been higher in the subprime segment; this might help explain why the initial propagation to MBS and related structured finance was concentrated in subprime loans, along with the details of the credit structuring emphasised by Gorton (2008). But as Figure 6 shows, the turning point in arrears rates was quite similar for prime (including some Alt-A) and subprime loans.

The generality of the increase in arrears rates also applies across securitised loans and those that remained on the balance sheet, which saw almost simultaneous increases (Figure 7, left-hand panel). Even if it was the strong investor demand for asset-backed paper that encouraged lenders to ease credit standards, it seems to have affected their entire lending business, not just the securitised portion.

The real distinction is between loans that were in the FHA pool or the conforming market - those insurable by the GSEs - and those that were not in either of those groups. Although there was some easing of standards in the conforming market, especially in the GSEs' extended programs and the FHA seller-financed downpayment program, it was minor compared with the one

\footnotetext{
${ }^{16}$ Tables 1 and 3 in Quercia et al. (2007) show that 20\% of subprime refinance loans originated in 1998 or 1999 went into foreclosure at least once by the end of 2003. Of these, around $60 \%$ ended in loss of the home.
} 
that occurred in the rest of the market. Arrears rates on the GSEs' singlefamily home portfolio have risen a great deal recently, but this only started in the second half of 2007 (Figure 7, right-hand panel). Likewise, the increase in arrears rates on FHA mortgages has been fairly mild.

\section{Figure 6 US Mortgage Areas Rates by Risk Grouping (\%)}

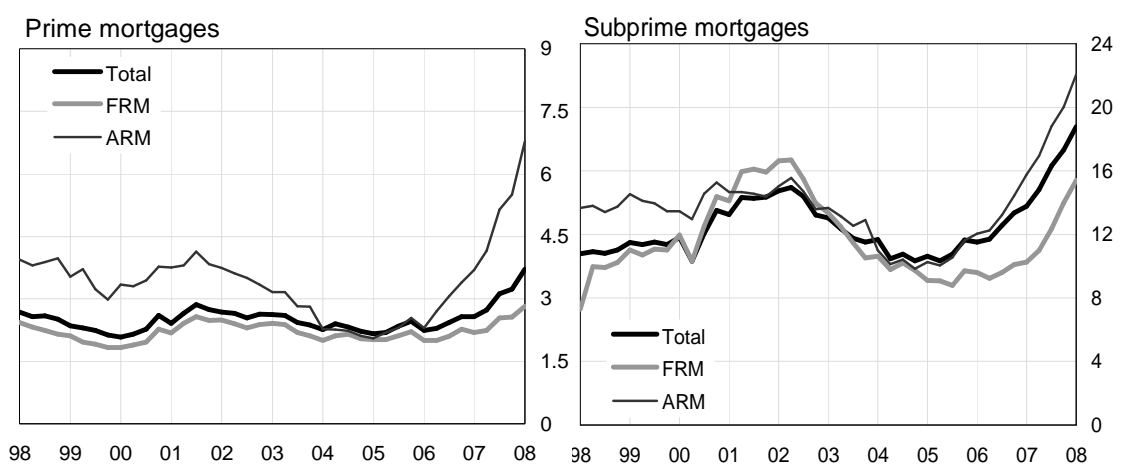

Note: Shows all loans at least 30 days delinquent or in foreclosure.

Source: Mortgage Bankers Association via DataStream.

\section{Figure 7 Bank and GSE Mortgage Arrears Rates (\%)}

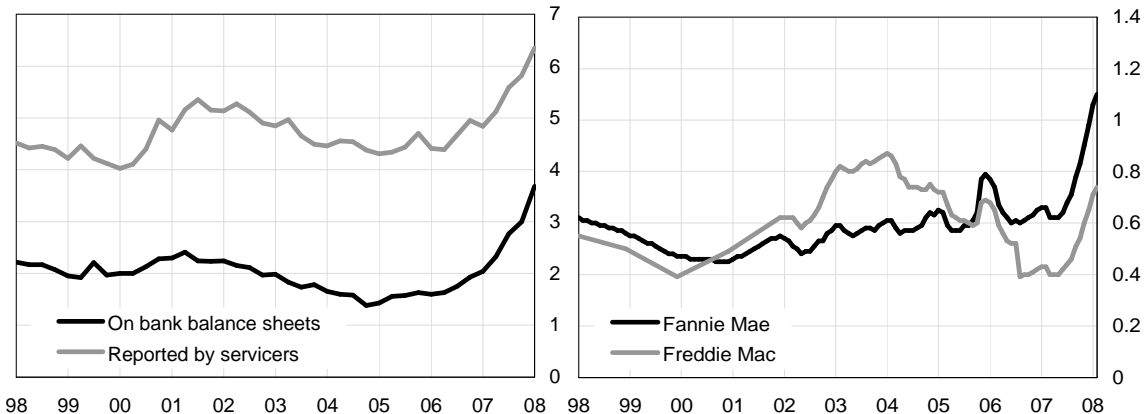

Sources: Fannie Mae, Freddie Mac, Federal Reserve and Mortgage Bankers Association via DataStream.

This is not to say that the subprime and non-Agency prime markets behaved identically or that the easing in lending standards was the same in both segments. Dell' Ariccia et al. (2008) show clear differences in the behaviour of denial rates on mortgage applications between the two lender types. Subprime lenders reduced denial rates in the face of larger application volumes and increased local competition from large national lenders. In contrast, prime lenders were little affected by new entrant lenders and tended to increase denial rates as applications increased. Despite these differences, however, 
arrears rates began to rise around the same time in both markets. This suggests that other aspects of easing lending standards were also important contributors to the subsequent increases in arrears rates.

Other countries have subprime lending in some form; for many others, there is no law preventing it from developing. So a complete answer to the question of why the mortgage meltdown and credit losses were a US-specific problem cannot stop at the point of noting that the United States ended up with more subprime lending. It is also important to ask why that occurred, and why US subprime lending seemed to have involved loan features that boosted arrears rates, independent of the outward creditworthiness of borrowers. In contrast to the US experience, initial LTV ratios remained low in the UK adverse credit mortgage sector, the closest equivalent to the US subprime sector (Bank of England 2007), and arrears have not ratcheted upwards in the same way.

Crews Cutts and Van Order (2004) survey the US subprime market in the early phases of its expansion. They emphasise the discontinuities inherent in a mortgage market segmented between prime and specialist subprime lenders, and suggest that this market structure might have been the result of lender attempts to get borrowers to reveal asymmetric information about themselves (a separating equilibrium). One corollary of this is that borrowers have private information about their quality that FICO scores do not capture. More importantly for subsequent outcomes, it implies that the reduction in conforming origination activity from 2004 (see Figure 3) brought to the fore lenders with very different business models from those of prime lenders. In particular, the separating equilibrium implies that subprime lenders do less underwriting than prime lenders, even though their customers are riskier.

\section{Understanding the Institutional Drivers of the Differences}

\subsection{Supply of New Housing Is Relatively Flexible}

An important institutional difference between the United States and some of the other countries discussed here relates to the build-up of housing oversupply documented in Section 2.1. Essentially, the elasticity of housing supply is higher in the United States than in countries such as the United Kingdom, and the long-term response is less drawn out than in Australia (Berger-Thomson and Ellis 2004). With a larger quantity response, housing prices rise by less in the face of a given increase in demand for housing. Normally, this flexibility is held to be a good thing because it limits the price overvaluation that can occur when demands for housing increases quickly, given inherently sluggish supply. When the increase in demand is temporary, however, for example driven by a temporary easing in credit standards, it is not so obvious that this supply flexibility is unreservedly beneficial. 
One underlying reason of the higher US supply elasticity is that less of the housing stock is subject to tight zoning laws and other restrictions that might restrict supply and boost housing prices (Glaeser and Gyourko 2003a, Glaeser and Gyourko 2003b). While such restrictions are important in a number of high-cost, mainly coastal centres in the United States, in many inland regions, new supply are relatively unrestricted. Regions with tighter zoning restrictions also tend to be the ones where geographical constraints on building (oceans, steeply sloped areas) are greatest (Glaeser, Gyourko and Saiz 2008), so the pattern of supply elasticities would probably exist even without zoning laws.

In the most recent US housing boom, the increased demand for housing did seem unusually concentrated in regions where supply could accommodate it most rapidly, namely as single-family homes built in exurban regions such as southern California's Inland Empire, or the regions around desert state cities such as Phoenix (Arizona) and Las Vegas (Nevada). Indeed, in contrast to the 1980s boom (Glaeser et al. 2008), recent evidence suggests that the "bubble" component of US housing prices was greatest in some cities, such as Las Vegas, where the elasticity of housing supply is higher than the national average (Goodman and Thibodeau 2008). Other centres such as Atlanta had relatively small price booms, because supply could respond, but have not thereby avoided the subsequent bust. By contrast, in high-demand coastal cities, prices rose but there was little pick-up in housing supply and, significantly, subprime and other non-conforming lending was much less prevalent (Mayer and Pence 2008).

Figure 8 (left-hand panel) shows how unusual the recent US housing supply cycle was relative to those of the past. In past upswings, the single-family share of housing starts remained fairly steady. It only ratcheted up during the subsequent downswing in overall activity, as condominium projects were canceled disproportionately. Over the period 2000-2006, however, both housing starts and the single-family share within them rose, pointing to an unusual concentration of the increase in suburban and exurban regions.

Data limitations, especially on city-level construction costs, preclude a crosscountry comparison of city-level supply elasticities along the lines of Goodman and Thibodeau's (2008) results for the United States. Nonetheless, the right-hand panel of Figure 8 provides some suggestive evidence that the apparently regional booms reflected US households moving where the houses were, rather than being motivated by more traditional labour market incentives. The first three cities/regions in that panel show the patterns that emerge when a particular city or region experiences a regionally specific demand shock that encourages inward migration. In the case of Perth (Australia) and Alberta province (Canada), the shock is the current mining boom (2003-end-2007). For San Francisco in the 1990s, the shock was the tech boom (1997-end-2000). In each of these cases, housing prices rose more rapidly than the national average: the cumulated growth over the boom period was more than double 
that of the nation as a whole. Employment and population growth also exceeded the national figures. But the source of the inward pull is also clear: even though the ratios of national employment to total population increased by around 2 percentage points over these periods, the employment-population ratios in Perth, Alberta and San Francisco increased even more.

\section{Figure 8 Housing Construction and Relative Housing and Labour} Market Performance

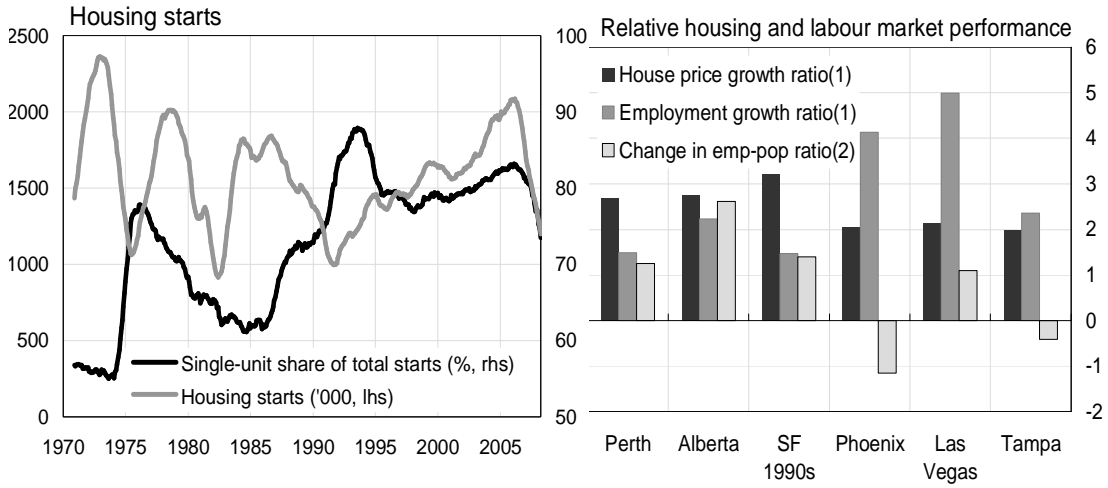

Note: Figures for Perth (Australia) and Alberta (Canada) are for January 2003 December 2007; for San Francisco, January 1997-December 2000; for Phoenix, Las Vegas and Tampa, January 2002-December 2006. Employment growth and change in employment to population ratio for Las Vegas refer to Nevada State.

(1) Ratio of percentage change in house prices / employment over period, to corresponding percentage change for the whole nation.

(2) Difference between change in employment-population ratio for the city/region and that for the whole nation, in percentage points. Population figures are whole population, not working-age population.

Sources: Australian Bureau of Statistics, National Sources via DataStream

By contrast in the three cities on the right of the panel - Phoenix, Las Vegas and Tampa, Florida - housing prices also rose at around double the national rate over the period 2002-2006, despite a substantial increment to the housing stock over the same period. All three cities were attracting substantial inward migration: employment increased by around 20 per cent in Phoenix and nearly one-quarter in Las Vegas, compared with the 5 per cent increase in employment at the national level. However, the employment-population ratio increased by only 1.2 percentage points in Las Vegas, and actually fell in Phoenix and Tampa (the national ratio was broadly flat over this period). New homes were being built to house the new residents, but the picture seems to be that these new households were going to where the new, higher-quality homes were, rather than being pulled to a region of high job opportunities, perhaps because many of them were already retired. This was probably further encouraged by the apparently high geographic mobility of the US population. 
No wonder that the housing price boom was initially characterised as being regional in nature (Greenspan 2005, for example). With hindsight, a better characterisation might have been of strong demand for housing nationally, stimulated by easier credit that manifested itself where supply could accommodate it the most. By concentrating the increases in both demand and supply geographically, the US institutional and geographical structures seem to have maximised the potential for build-up of excess supply in at least some regions. Now that the boost to demand from easier credit has been withdrawn and homes a long distance from employment centres have become less attractive as gasoline prices rise, it seems hard to imagine that this supply overhang will be worked off quickly, without a substantial fall in prices in these regions.

\subsection{Tax System Encourages Higher Leverage and Flipping}

In the United States, interest on mortgages for owner-occupied homes is deductible against income tax. The imputed rent from owning one's home and not paying rent to a landlord is likewise free of tax. Both of these aspects of the tax system encourage households to buy their own home. The US system differs from many others in that it has both features (see Table 2): only Spain comes close, and the tax credits there do not apply to all borrowers. ${ }^{17}$ Numerous countries - including most other English-speaking countries - do not tax imputed rent, but do not allow interest on owner-occupied mortgages to be deducted. In countries such as Switzerland and the Netherlands, mortgage interest can be deducted against tax, but households also pay tax on the estimated imputed rent or the value of the home. In either case, the implicit subsidy to homeownership through the tax system is less than in the United States, though by how much depends on the relative tax rates and the way that imputed rents are calculated.

Encouraging home ownership has long been an explicit policy goal in the United States, so these differences in taxation arrangements are not surprising. One effect of them, though, is that US households have less incentive to pay off an owner-occupied mortgage quickly. Because they are paying it out of pretax, not post-tax, income, they are more likely to find it worthwhile to borrow against their homes and accumulate more non-housing assets. In addition, the value of prepaying a mortgage ahead of schedule is lower than if the interest is non-deductible. US households therefore have more incentive to keep the LTV ratio high on an ongoing basis. This might explain some of the differences described in the previous sections, namely a greater prevalence of interest-only mortgages and the rapid increase in cases of negative equity. Mortgage interest was also tax-deductible in the Nordic countries at the time of their credit booms in the 1980s; this has previously been cited as one of the contributing

\footnotetext{
${ }^{17}$ Although not all US taxpayers itemise deductions (Himmelberg, Mayer and Sinai 2005), it seems reasonable to suppose that the marginal borrower does.
} 
factors to the size of the boom in household borrowing (Drees and Pazarbasiouglu, 1998).

Table 2 Taxation Arrangements Affecting Housing and Mortgages in Selected Countries

\begin{tabular}{|c|c|c|c|c|c|c|}
\hline \multirow{2}{*}{ Country } & \multirow{2}{*}{$\begin{array}{c}\text { Own-home } \\
\text { Interest } \\
\text { Deductibility }\end{array}$} & \multicolumn{3}{|c|}{ Own Home Free of Tax on: } & \multicolumn{2}{|c|}{$\begin{array}{c}\text { Investor Property } \\
\text { Attracts: }\end{array}$} \\
\hline & & $\begin{array}{c}\text { Capital } \\
\text { Gains }\end{array}$ & Wealth & $\begin{array}{c}\text { Imputed } \\
\text { Rent }\end{array}$ & $\begin{array}{l}\text { Capital } \\
\text { Gains }^{1}\end{array}$ & $\begin{array}{l}\text { Negative } \\
\text { Gearing } \\
\end{array}$ \\
\hline US & Yes & $\mathrm{Yes}^{3}$ & Partly $^{4}$ & Yes & Full & $\mathrm{No}^{5}$ \\
\hline UK & No & Yes & Yes & Yes & Full & No \\
\hline Australia & No & Yes & Limited $^{6}$ & Yes & Part & Yes \\
\hline Canada & No & Yes & Yes & Yes & Part & $\mathrm{Yes}^{7}$ \\
\hline France & No & $\mathrm{Yes}^{8}$ & Limited & Yes & $\mathrm{Part}^{8}$ & Part \\
\hline Germany & No & Yes $^{8}$ & Limited & Yes & $\operatorname{Part}^{8}$ & Yes \\
\hline Ireland & No & Yes & Yes & Yes & Part & No \\
\hline Neth. & Yes & Yes & No & No & None & No \\
\hline NZ & No & Yes & Limited $^{6}$ & Yes & None & Yes \\
\hline Spain & Partial & Yes & Yes & Yes & Full $^{9}$ & From $2007^{10}$ \\
\hline Sweden & Yes & No & No & No & Part & Yes \\
\hline Switz. & Yes & No & No & No & Yes & No \\
\hline
\end{tabular}

Note:The first four columns and the last column of the table are specified so that a "Yes" entry indicates a more favourable tax treatment than a"No"or"Partly/Limited"entry.

1. "Part" implies concessional rate compared with marginal tax rate applying to labour income.

2.Refers to ability to deduct mortgage interest and other costs accruing to landlords from labour as well as rental income.

3. In most cases, capital gains can be carried over.

4.Local property taxes.

5.Only professional property investors can write off against other income.

6. Local rates loosely linked to property values.

7.Cash costs only.

8. Exemption subject to a long holding period.

9. on inflation-adjusted gains.

10. Negative gearing first allowed in Spain in 2007

*Taxation arrangements for buy-to-let property in Ireland are discussed in the "Rental income" brochure available on the website of the Revenue Commissioners (http://www.revenue.ie/index.htm?/leaflets/it70.htm ). For Spain, the information is available (in Spanish) from the website of the Agencia Tributaria (http://www.aeat.es/).

The rest of the table was combined from the secondary sources cited.

Sources: Haffner and Dol (2000), van den Noord and Heady (2001), RBA (2003d),

Scanlon and Whitehead(2004),Committee on the Global Financial System(2006),Ellis

(2006),Irish Revenue Commissioners, Agencia Tributaria d'España(Spanish Tax Office).

These tax differences interact with the greater tendency to refinance described below in Section 3.6. When mortgage interest is paid out of pre-tax income, the opportunity cost of refinancing the mortgage to a higher amount is less than if 
interest is not deductible. As the boom wore on, it seems that many households were repeatedly refinancing to liquefy the increasing value of their homes.

Even some long-standing home owners were left with little equity cushion.

Another possible consequence of these tax arrangements is that speculative demand is relatively more likely to manifest as "flipping" (buying and selling soon afterwards), rather than renting the property out to a tenant. In contrast, in countries where mortgage interest is deductible against rental (and maybe other) income for a buy-to-let property, but not for an owner-occupied property or second home, it is preferable to actually let the property out. An inability to rent the property out will therefore provide a natural brake on the incentive to speculate in property, even if expected capital gains are still strong. By contrast, where speculation in property occurs through flipping, an overhang of excess housing can build up before lower sale prices signal this fact to investors. This could take some time in the housing market, given time-to-build lags and the noisy price signals provided by heterogeneous individual properties.

This is not to say that speculative demand from buy-to-let investors has played no role in housing price booms elsewhere. Small property investors have been identified as an important driver of demand in the booms in Australia (RBA 2003d) and the United Kingdom. Even so, because landlords in these countries have to make the property available for rent to claim the tax deduction, they received earlier signals about excess supply by being unable to find a tenant or by observing falling rents. Flippers, by contrast, will only learn that excess housing supply is building up once they or other investors start trying to sell the properties again, and prices start falling; this is especially true if they are concentrated in newly built districts with few comparable sales early on.

Since holding periods (even for "flippers") are likely to be longer than the lag between purchase and noticing difficulties in tenanting, US investors were able to create a larger overhang of rental properties, as well as properties intended for the homeowner market, before the price signals started to work through. Thus although there might have been some mismatches between demand and supply in some segments of the markets there (for example in inner-city rental apartments), the buy-to-let booms in Australia and the United Kingdom did not lead to an overall supply overhang as seen in the United States(see Section 2.1).

Even apparently small details of the tax system can influence outcomes in the mortgage market and hence credit quality. Avery et al. (2007) point out that one reason for the popularity of piggyback second-mortgages in the United States might be that interest payments on these mortgages are separately taxdeductible, while borrower payments for lenders' mortgage insurance were not, until recently. Borrowers who could only make a small downpayment, especially those in higher tax brackets, would therefore prefer to take out a piggyback loan than mortgage insurance for the whole amount, even if the cost 
of the higher interest rate on the piggyback was the same as the insurance premium.

\subsection{Legal System is Swift but Generous to Defaulters}

Households' decisions to default on their mortgage, and the financial sacrifices they are willing to make to stay current, are clearly related to the sanctions they face on default. In a pan-European comparison, Duygan and Grant (2006) find that the propensity to fall into arrears or to default in the face of an adverse income shock is closely related to the punishment incurred by doing so, which in turn depends on the legal framework.

The United States has long had a reputation for having a relatively generous bankruptcy system (a federal matter), though this was tightened in 2005. Indeed, under the law prevailing when arrears began to rise, mortgage debt could not be reduced as part of a bankruptcy agreement. Foreclosure law varies across states (Crews Cutts and Green 2004). It is often assumed that home mortgages are non-recourse in the United States - in other words, if the borrower defaults, the lender gets the home as collateral, but cannot pursue the borrower for any deficiency between the home's value and the remaining debt. In fact, deficiency judgements are possible in 44 of the 50 states, and in at least one of the six with non-recourse mortgages (California), this only applies to purchase mortgages and not refinancing. On paper, the US system therefore resembles those in countries such as the United Kingdom, where borrowers retain personal liability for the debt.

In practice, however, lenders tended not to seek deficiency judgements because they were seen as costly relative to the value that might be recouped. Around half of all US states (and of the states that prohibit deficiency judgements, all bar South Dakota) have a non-judicial foreclosure process - generally quicker and cheaper than systems where court action is required. Many lenders would take the view that it would be better to retrieve the collateral alone in a lowercost process, than to incur the legal costs of pursuing defaulting borrowers for any deficiency.

The US foreclosure process is also somewhat swifter than in some other countries. According to the data compiled by Crews Cutts and Green (2004), foreclosure proceedings can start in three months or less in half of all US states, and the delay exceeds six months only in Illinois and Vermont. The limited data available suggest that lenders in other countries must wait longer on average to start and to complete foreclosures and repossessions (Committee on the Global Financial System 2006). Delinquency data for the United Kingdom show that some lenders will still hold mortgages that have been delinquent for over a year.

The legal and mortgage systems in the United States have therefore interacted to produce a different tradeoff between speed and full asset recovery than 
elsewhere. As a result, when house prices are rising, many US lenders' incentives are tilted more strongly in favour of lending on the basis of collateral rather than affordability, than those of lenders elsewhere. If it turns out that the borrower cannot afford to repay the loan, the lender can access the collateral relatively quickly in at least half of all US states. Taking this together with differences in consumer protection regulation of mortgage lending itself, as described below in Section 3.5, it is no surprise that a lending sector with a collateral-based business model developed in the United States, and not in countries like the United Kingdom.

\subsection{Lenders Could Rely on External Credit Scores}

Another important difference between the US legal system and those of some other countries that experienced housing booms in recent years is that positive credit reporting is permitted and privacy laws allow this information to be widely shared. Credit reporting agencies can collect the entire history of a household's credit events and build up a comprehensive credit score such as the FICO score. By contrast in Australia, the Privacy Act permits only socalled negative credit reporting, of events such as missed payments and bankruptcy. This limits the amount of third-party information lenders can use in developing a widely available credit score. As a result, a US-style system, where a small number of scoring systems dominate across a range of different lending markets, has not emerged. Comprehensive credit reporting is possible in the United Kingdom, but lenders seem to construct their own credit scores rather than share them. ${ }^{18}$ MBS investors cannot then use a third-party score as a substitute for their own analysis.

While credit scoring clearly reduces costs and increases transparency in mortgage origination (Committee on the Global Financial System 2006), it holds a number of potential dangers. Firstly, analogously to credit ratings for structured credits, households' credit scores can be used for purposes for which they were not designed. The FICO score was designed to assess risks on credit cards and other short-term consumer credit, but was also used for mortgage lending. The short-term nature of the FICO score is especially apparent in the lower ranges mainly served by subprime lenders. Crews Cutts and Van Order (2004) present data from the late 1990 s showing that $30 \%$ of people with sub600 FICO scores had improved their score by more than 20 points within three months.

\footnotetext{
${ }^{18}$ The information on credit scoring practices in Australia and the United Kingdom is sourced from, among other places, the websites of the Australian Privacy Commissioner (http://www.privacy.gov.au/act/credit/index.html) and the UK Financial Services Authority (http://www.moneymadeclear.fsa.gov.uk/products/loans/credit/credit_reference_agenci es.html).
} 


\subsection{Financial Regulation Did Not Prevent Riskier Lending}

If lenders faced tight regulation that enforced prudent lending, the inherent tendency to higher LTV ratios driven by the US tax system, as described above, might not have actually shown up in actual lending practices. US households would then not have ended up in negative equity in such numbers. More generally, how lenders are regulated has obvious implications for the riskiness of mortgages offered and the propensity of borrowers to default.

The US mortgage market is subject to an array of laws and different regulators. The regulated GSEs enforced quality control in the conforming market, but the rest of the mortgage market was more lightly regulated. Mortgage lenders that were not also depositories were the lightest regulated of all. As one example of the relatively light regulation of many mortgage lenders, consider the new regulations announced by the Federal Reserve in December 2007 and approved in July 2008, as part of its role of enforcer of the Home Ownership and Equity Protection Act. Among the practices newly banned by these regulations were "coercing a real estate appraiser to misstate a home's value" and "making a loan without regard to borrowers' ability to repay the loan from income and assets other than the home's value" (Federal Reserve Board 2008). The implication is that these practices were permitted in the absence of the new regulation, and were common enough to merit an explicit ban. Had all US mortgage originators been bound by a requirement to consider the affordability of the repayment explicitly - as is the case under Australia's Uniform Consumer Credit Code or the requirements of UK legislation, ${ }^{19}$ for example it seems unlikely that no-documentation (stated-income) mortgages or "exploding ARMs" would have become so prevalent.

In addition, following intervention in 2004 by the Office of the Comptroller of the Currency (OCC), federally regulated lenders were exempted from state legislation which was in many cases stricter than that at the federal level. Some of the practices banned under some states' law included the prepayment penalties and balloon payments that have been shown to raise default rates, independent of the borrower's credit score (Quercia et al. 2007).

\subsection{Cash-out Refinancing is Inexpensive in the United States}

The mortgage market in the United States has several unusual features that are seen in few other countries. As described in Green and Wachter (2005) and elsewhere, the US mortgage system evolved to receive indirect government

\footnotetext{
${ }^{19}$ Information on Australia's Uniform Consumer Credit Code can be found at http://www.creditcode.gov.au/. Enforcing fairness in UK mortgage lending is part of the remit of the Financial Services Authority, under the terms of the Unfair Terms in (http://www.opsi.gov.uk/si/si1999/19992083.htm) Consumer Contracts Regulations 1999, as amended in 2001(http://www.opsi.gov.uk/si/si2001/20011186.htm).For more information see http://www.fsa.gov.uk/Pages/Doing/Regulated/consumer/index.shtml.
} 
support via the GSEs. The GSEs were long able to fund themselves in capital markets at advantageous rates. They insure mortgages with standardised features and risk characteristics. A particular feature of the US system is that it allows long-term fixed-rate mortgages (FRMs) to be refinanced at low cost. This means that US households can take advantage of falls in long-term rates while being protected from increases, something that is only possible in the United States and Denmark (Frankel, Gyntelberg, Kjeldsen and Persson 2004). Housing market outcomes differ materially when mortgages are predominantly at fixed rates rather than variable rates (Tsatsaronis and Zhu 2004). In particular, house prices respond less to monetary policy, and more to shocks to private-sector credit, such as an easing in credit standards. This has clear implications for the US economy's sensitivity to lending booms.

Fixed-rate mortgages have to be explicitly refinanced to obtain a lower rate. US prime borrowers in particular will refinance aggressively when current fixed mortgage rates fall far enough below the rates they are currently paying. Once rates start to rise again, most borrowers will only refinance if they wish to take cash out (Figure 9, left-hand panel). The US mortgage system therefore seems to have evolved to be set up for a higher ratio of origination to outstanding, than systems where loans are mostly ARMs, or where refinancing of fixed rate loans is either expensive or not permitted. Origination capacity increased even more relative to market size during the refinancing wave of 2003 (See Section 2.2).It cannot be ruled out that brokers and lenders subsequently sought to keep volumes up by pursuing ever more marginal borrowers, rather than scaling their operations back again.

\section{Figure 9 Cash-out Refinancing and OFHEO Housing Prices}
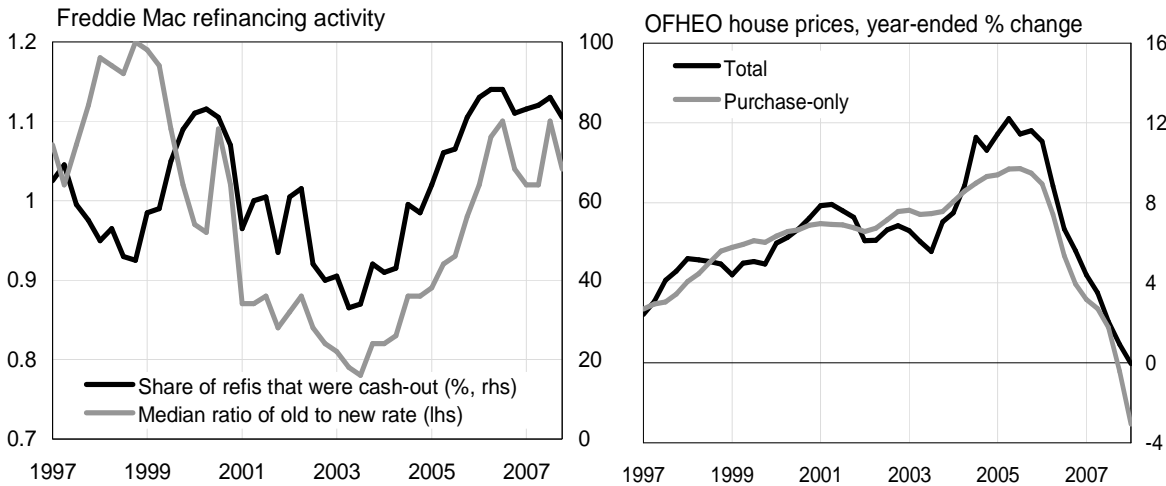

Sources: Freddie Mac and OFHEO via DataStream

The shift towards ARMs with initial teaser interest rates should perhaps be seen in this context as well. As documented in Foote et al. (2008a), teaser rates on many subprime mortgages were not that low, and most borrowers of these 
loans refinanced before or soon after their rate reset. Both lenders and borrowers seemed to understand that this was the intention. Rather than being a means of reaping a higher post-reset payment from borrowers, teaser rates seem to have been a device to maintain origination volumes through refinancing. On top of the incentives provided by origination fee income, Gorton (2008) points out that subprime mortgages were designed to force frequent refinancing, because this limited the horizon of lenders' exposures to these borrowers. The combination of teaser rates and prepayment penalties thus effectively shifted the option to default from the borrower to the lender (by choosing not to refinance).

The differences between ARMs held for long periods and frequently refinanced fixed-rate loans are especially apparent when non-price lending conditions tighten. A borrower with an adjustable-rate loan is immediately exposed to interest rate changes. If the fixed-rate borrower wants to refinance, however, they also have to meet current non-price lending conditions like LTV ratios. In contrast, if maximum LTV ratios are cut for adjustable-rate loans, existing borrowers are not affected, only new ones. Thus the US system is potentially more susceptible to tighter credit standards than those in countries where refinancing is less common.

A further implication of inexpensive refinancing is that cash-out refinancing are also inexpensive. When households refinance more often, they have more opportunities to increase their loan balances than in systems where refinancing is comparatively rare. Amongst recent subprime (securitised) refinance loans, around 90 per cent involved some cashing out (Mayer and Pence 2008). Frequent cashing out implies that ongoing LTV ratios would be higher in the United States for a given initial LTV ratio.

Frequent refinancing also means that more mortgages are originated based on appraisals rather than market prices. If appraised values of refinanced homes had been overstated compared with sale prices during the boom, refinancing borrowers would end up more vulnerable to falls in market prices. Some evidence of appraisal inflation is apparent in the divergence between the OFHEO house price index including refinancing (based on appraised value) and the purchase-only index (Figure 9, right-hand panel). Moreover, these data refer to prime loans refinanced by the GSEs; if the figures had included subprime and other non-conforming mortgages, this difference would probably have been even larger.

\subsection{Structured Finance Enabled Subprime and Other Non-conforming Lending}

All securitisation markets face information asymmetries that can encourage lax lending standards (Ashcraft and Schuermann 2008). Investors in MBS therefore need to conduct due diligence to prevent asymmetric information turning into imprudent lending. In the recent credit boom, however, many 
seemed content to rely on ratings rather than doing their own risk assessment of either the MBS or the structured securities based upon them.

Analogously, MBS investors also relied too heavily on FICO scores as an indicator of mortgage borrower creditworthiness. This provided another incentive for originators to relax lending standards. As documented by Keys, Mukherjee, Seru and Vig (2008), a score of 620 or above had traditionally been the threshold above which a mortgage would be eligible to be bought by the GSEs. The same threshold became the standard one for private-label (nonGSE) securitisation as well. Therefore mortgage originators would know that if the borrower had a score of 620 or above, market practice implied that it was more likely that the loan could be securitised. Keys et al. (2008) show that lending standards were noticeably laxer and subsequent loan performance worse, slightly above the 620 threshold, compared with the mortgage loans where the borrower's score was slightly below 620 . Their findings provide direct evidence that lenders eased standards significantly if they thought the loan was likely to be securitised, which implies that the information asymmetries inherent in the securitisation process were not being corrected by investor due diligence in this period.

Most securitisation deals contained "put-back" clauses that meant that lenders had to buy back early delinquencies out of the MBS structures. These clauses were intended to give mortgage originators the incentive to lend prudently (Gorton 2008), but the wave of bankruptcies of subprime lenders in late 2006 and early 2007 suggests that they did not appreciate how risky their own lending had become. Alternatively, it may have been that put-back clauses were not a meaningful discipline on lenders that had no balance sheets of their own, and therefore had neither the capacity nor the intention to honour putbacks.

This shift in underwriting practices occurred at the same time as credit conditions globally were relatively easy. Demand for structured credit products increased rapidly over the course of the decade; mortgages and MBS often served as the underlying assets behind these products. Loans labeled as subprime started to be securitised with increasing frequency (Mayer and Pence 2008), whereas prior to the lending boom, subprime lenders had been less likely to package their loans for securitisation than prime lenders (Crews Cutts and Van Order 2004).

Demand for structured credit products did not just influence the behaviour of existing mortgage lenders. It seems that it also encouraged entry into the market. In particular, many major US investment banks and some international ones acquired subprime lending subsidiaries during the boom's run-up phase. As providers of wholesale funding lines for other lenders, they also encouraged existing lenders to enter new geographical markets. Dell' Ariccia et al. (2008) find that one driver of the deterioration in subprime (and to a lesser 
extent, prime) lending standards is the entry of some large national players into new local markets. The resulting increased competition encouraged incumbent lenders to ease their lending standards, with similar results to the easing by manufactured housing lenders some years earlier (Committee on the Global Financial System 2005). In contrast, there were fewer new entrants into the UK or Australian markets recently, for example, since these had already seen an increase in competition in the 1990s.

This raises the deeper issue of why there were new entrants in US mortgage market but not in other countries to the same extent. While the investor appetite for asset-backed instruments encouraging the securitisation boom was global, it manifested itself the most in the market where securitisation was used the most. Whether this was due to the size of the underlying mortgage market, its denomination in US dollars, or the willingness of lenders there to ease standards to meet that demand, is not immediately clear. However, many non-US issuers of RMBS did so in US dollars (and swapped the currency risk) without seeing the same decline in loan quality. This suggests that the disproportionate rise in US-originated issuance may well have something to do with the willingness of US originators to ease underwriting standards.

One reason why the strong demand for structured finance led to the structuring of specifically US-domiciled assets might have been that the externalisers of the credit risk were primarily US-domiciled entities such as municipal bond insurers (monolines). These entities were willing to insure the senior tranches of the structures more cheaply than other means of providing credit protection, including over-collateralisation and traditional mortgage insurance on the underlying mortgages, which remained common for securitisations in other countries. In turn, monoline bond insurers were concentrated in the United States because their primary business in the municipal bond market is concentrated there. In many other jurisdictions, higher-rated state and national governments underwrite local government bond issuance, or even raise funds on their behalf. The services of the monolines were therefore not required to the same extent outside the United States.

\section{Concluding Remarks and Some Policy Lessons}

As has been pointed out many times elsewhere, the recent financial turmoil was propagated globally because of an increase in risk-taking. The problems in the US mortgage market could just be seen as the trigger for the more generalised turmoil. By this view, the initial shock could easily have been from somewhere else. It is nonetheless still worth asking why the US mortgage market was the trigger. Housing construction and prices have boomed in many countries of late. Other than in the United States, housing prices only began to fall in earnest, and arrears rates rise, once there was a shock external to the 
housing market, such as a macroeconomic contraction or a collapse in mortgage credit supply.

Many of these countries are arguably at least as far along in their housing cycles as the United States, or not much behind it, so this is probably not just a matter of lags; instead it suggests that the downswings have not had the same implications for housing mortgage arrears. To the extent that that housing markets have contracted in countries such as Ireland, Spain and the United Kingdom in the recent period, it has reflected the macroeconomic downturn, not instigated it: this is the opposite sequence of events to what happened in the United States, where rising arrears rates spurred tighter credit. Moreover, it seems very unlikely that some of the other features of the US meltdown - a substantial oversupply of housing, early payment defaults, abuse of statedincome loans and so on - will be seen to be significant in most other countries. The available evidence presented in this paper provides some support for the idea that this was a US-specific housing meltdown because the contributing factors all went further in the United States than elsewhere. Overbuilding of new housing, easier lending standards and the sensitivity of arrears rates and the incidence of negative equity to falling housing prices all seem to have been at least somewhat more pronounced in the United States.

The US housing construction sector seems to have managed to build up a substantial oversupply of housing. The United States was therefore more likely to experience a sharp fall in prices than some other countries, even before credit supply tightened. Mortgage lending standards also eased more: only in the United States was there such a rapid expansion of subprime, no-deposit, stated-income, teaser and negative-amortisation mortgage products (sometimes all of these features in the one loan). Households were therefore more likely to fall into negative equity, and if they did, to default on their mortgages.

On top of these proximate factors, though, the US housing-finance system was more sensitive to such an easing in credit standards. Geographic factors and the land-use planning system allowed builders to expand the housing supply more than elsewhere. The tax system encouraged households to maintain high ongoing LTV ratios, and the legal and regulatory systems enabled lenders to ease standards and thereby further encourage households to increase their initial LTV ratios, and keep them high. Given all these factors working in the same direction and interacting with each other, the United States could well have experienced a painful bust and rising arrears rates, even if the easing in credit standards had not been greater than elsewhere.

The recent distress in US mortgage markets has demonstrated the potential negative consequences of a temporary easing in lending standards. One lesson from this is that institutional differences shape the response to global financial developments, and the interaction between these institutional details can make a large difference to the end result. In countries where housing supply is especially flexible, and where tax and finance systems are very advantageous 
toward housing, an easing in credit standards on home mortgages might have particularly costly consequences, especially once standards tighten again. This might point to the need for stricter regulation of mortgage underwriting in those countries compared with elsewhere, in order to prevent excessive easing of lending standards.

As well as tighter regulation, authorities concerned with financial stability in countries with such an institutional setup need to be even more vigilant than their counterparts elsewhere in watching for signs of speculative imbalances in their housing markets. "Soft" signals, such as the presence of overt speculative activity, or the availability of mortgage products that the borrower cannot reasonably sustain over its full life, are especially useful. Monitoring of underwriting standards of both mainstream and fringe lenders, and the importance of the latter in the market, is needed to make that assessment.

Finally, more attention needs to be paid to institutional differences across countries when assessing their financial stability. The factors identified in this paper as contributing to the US housing meltdown were in many cases longstanding institutional features, and were certainly not secrets. Why, then, did so many observers miss the United States' greater vulnerability? We can probably do no more than speculate on the answer to this question, but the available literature covering the boom suggests that two cognitive biases were present. Much of the commentary on the US boom did not look further afield to notice how singular some US developments and institutions really were. Meanwhile much of the cross-country analysis published by international financial institutions and others was focused more on drawing out the common factors, and therefore glossed over the differences.

\section{Acknowledgement}

This paper was written while I was on secondment to the Bank for International Settlements. I would like to thank Clara Garcia for consistently excellent research assistance, and Ingo Fender, Jacob Gyntelberg, Christian Upper and participants at an internal BIS seminar for helpful comments and suggestions. The views expressed in this paper are those of the author and should not be attributed to the RBA, the BIS or the other staff of either organisation. 


\section{References}

Ashcraft, A. B. and Schuermann, T. (2008). Understanding the Securitization of Subprime Mortgage Credit, Staff Report 318, Federal Reserve Bank of New York.

Attanasio, O. P. and Weber, G. (1994). The UK Consumption Boom of the Late 1980s: Aggregate Implications of Microeconomic Evidence, Economic Journal, 104, 427, 1269-1302.

Avery, R. B., Brevoort, K. P., and Canner, G. B. (2007). The 2006 HMDA Data, Federal Reserve Bulletin, 93, A73-A109.

Bank of England (2007). Financial Stability Review, London: Bank of England.

Barker, K. (2004) Delivering Stability: Securing Our Future Housing Needs (Barker Review of Housing Supply), London: HM Treasury, http://www.hmtreasury.gov.uk/consultations and legislation/barker/consult barker_index.cf $\underline{\mathrm{m}}$.

Barth, J. R. and Yezer, A. M. J. (1983). Default Risk on Home Mortgages: A Further Test of Competing Hypotheses, Journal of Risk and Insurance, 50, 3, $500-505$.

Bean, C. (2008). Walking the Tightrope: Prospects for the UK Economy, speech given to Members of the Community of the Ismaili Centre, 17 April 2008.

Benito, A. (2006). The Down-payment Constraint and UK Housing Market: Does the Theory Fit the Facts? , Journal of Housing Economics, 15, 1, 1-20.

Berger-Thomson, L. and Ellis, L. (2004). Housing Construction Cycles and Interest Rates, Research Discussion Paper 2004-08, Reserve Bank of Australia.

Bernanke, B. (2008). Mortgage Delinquencies and Foreclosures, Speech given at Columbia Business School's 32nd Annual Dinner, New York, New York, May 5.

Bhardwaj, G. and Sengupta, R. (2008). Where's the Smoking Gun? A Study of Underwriting Standards for US Subprime Mortgages, Research Division Working Paper 2008-036A, Federal Reserve Bank of St Louis.

Blundell-Wignall, A. and Atkinson, P. (2008). The Subprime Crisis: Causal Distortions and Regulatory Reform, in Lessons from the Financial Turmoil of 2007 and 2008, Reserve Bank of Australia Conference, Reserve Bank of Australia. 
Brooks, R. and Simon, R. (2007). Subprime Debacle Traps Even Very Creditworthy, in Wall Street Journal, 3 December, http://online.wsj.com/article/SB119662974358911035.html.

Bucks, B. K., Kennickell, A. B., and Moore, K. B. (2006). Recent Changes in U.S. Family Finances: Evidence from the 2001 and 2004 Survey of Consumer Finances, Federal Reserve Bulletin, 92, 1, A1-A38.

Cagan, C. L. (2007). Mortgage Payment Reset - The Issue and the Impact, First American Core Logic White Paper, 19 March.

Committee on the Global Financial System (2005). The Role of Ratings in Structured Finance: Issues and Implications, Bank for International Settlements CGFS Papers 23.

Committee on the Global Financial System (2006). Housing Finance in the Global Financial System, Bank for International Settlements CGFS Papers 26.

Concentrance Consulting Group (2005). An Examination of Downpayment Gift Programs Administered by Non-profit Organizations, Contract Report C$O P C$-22550/M0001, Department of Housing and Urban Development.

Crews Cutts, A. and Green, R. K. (2004). Innovative Servicing Technology: Smart Enough to Keep People in Their Houses? Working Paper 04-03, Freddie Mac.

Crews Cutts, A. and Van Order, R. (2004). On the Economics of Subprime Lending, Working Paper 04-01, Freddie Mac.

Dell'Ariccia, G., Igan, D., and Laeven, L. (2008). Credit Booms and Lending Standards: Evidence from the Subprime Mortgage Market, CEPR Discussion Paper 6683, London: Centre for Economic Policy Research.

Demyanyk, Y. and Van Hemert, O. (2007). Understanding the Subprime Mortgage Crisis, Supervisory Policy Analysis Working Papers 2007-05, Federal Reserve Bank of St. Louis.

Deng, Y., Quigley, J., Van Order, R., and Mac, F. (1996). Mortgage Default and Low Downpayment Loans: The Costs of Public Subsidy, Regional Science and Urban Economics, 26, 263-285.

Diaz-Serrano, L. (2005). Income Volatility and Residential Mortgage Delinquency across the EU, Journal of Housing Economics, 14, 3, 153-177. 
Drees, B. and Pazarbasiouglu, C. (1998). The Nordic Banking Crises: Pitfalls in Financial Liberalization, Occasional Paper 98/161, International Monetary Fund.

Duygan, B. and Grant, C. (2006). Households Debt and Arrears: What Role Do Institutions Play?, In Financial System Modernisation and Economic Growth in Europe, number 7 in ECB-CFS Conference, Berlin: Deutsche Bundesbank.

Egebo, T., Richardson, P., and Lienert, I. (1990). A Model of Housing Investment for the Major OECD Economies, OECD Economic Studies, 14, 152-188.

Ellis, L. (2006). Housing and Housing Finance: The View from Australia and Beyond, Research Discussion Paper 2006-12, Reserve Bank of Australia.

Ellis, L. (2008). How Many in Negative Equity? The Role of Mortgage Characteristics, BIS Quarterly Review, December, 81-93.

Epperson, J. F., Kau, J. B., Keenan, D. C., and Muller, W. J. (1985). Pricing Default Risk in Mortgages, Journal of the American Real Estate and Urban Economics Association, 13, 3, 261-272.

Federal Reserve Board (2008). Highlights of Final Rule Amending Home Mortgage Provisions of Regulation Z (Truth in Lending), 14 July 2008, available at

http://www.federalreserve.gov/newsevents/press/bcreg/E1515A7162514E5EA D0C295B038E101F.htm.

Foote, C. L., Gerardi, K., Goette, L., and Willen, P. S. (2008a). Subprime Facts: What (We Think) We Know About the Subprime Crisis and What We Don't, Public Policy Discussion Paper 08-2, Federal Reserve Bank of Boston.

Foote, C. L., Gerardi, K., and Willen, P. S. (2008b). Negative Equity and Foreclosure: Theory and Evidence, Public Policy Discussion Paper 08-3, Federal Reserve Bank of Boston.

Foster, C. and Van Order, R. A. (1985). FHA Terminations: A Prelude to Rational Mortgage Pricing, Journal of the American Real Estate and Urban Economics Association, 13, 3, 273-291.

Frankel, A., Gyntelberg, J., Kjeldsen, K., and Persson, M. (2004). The Danish Mortgage Market, BIS Quarterly Review, 95-109.

GAO (2007). Information on Recent Default and Foreclosure Trends for Home Mortgages and Associated Economic and Market Developments, Report 
presented to the US Congressional Committee on Financial Services GAO-0878R, United States Government Accountability Office, 16 October, available at http://www.gao.gov/new.items/d0878r.pdf.

Gerardi, K., Lehnert, A., Sherlund, S., and Willen, P. (2008). Making Sense of the Subprime Crisis, in Brooking Papers on Economic Activity September 2008 Conference.

Glaeser, E. L. and Gyourko, J. (2003a). The Impact of Building Restrictions on Housing Affordability, Federal Reserve Bank of New York Economic Review, 9, 2, 21-43.

Glaeser, E. L. and Gyourko, J. (2003b). The Impact of Zoning on Housing Affordability, Economic Policy Review, 9, 2, 21-39.

Glaeser, E. L., Gyourko, J., and Saiz, A. (2008). Housing Supply and Housing Bubbles, NBER Working Paper 14193, National Bureau of Economic Research.

Goodman, A. C. and Thibodeau, T. G. (2008). Where Are the Speculative Bubbles in US Housing Markets? , Journal of Housing Economics, 17, 2, 117137.

Gorton, G. (2008). The Panic of 2007, in Maintaining Stability in a Changing Financial System, Jackson Hole Symposium, Federal Reserve Bank of Kansas City.

Gramlich, E. M. (2007). Subprime Mortgages: America's Latest Boom and Bust, Washington, DC: Urban Institute Press.

Green, R. K. and Wachter, S. M. (2005). The American Mortgage in Historical and International Context, Journal of Economic Perspectives, 19, 4, 93-114.

Greenspan, A. (2005). Testimony before the Joint Economic Committee, U.S. Congress June 9, 2005, available at http://www.federalreserve.gov/BOARDDOCS/TESTIMONY/2005/20050609 2/default.htm.

Haffner, M. E. A. and Dol, C. P. (2000). Housing Statistics in the European Union, Delft: OTB Research Institute for Housing, Urban and Mobility Studies.

Haughwout, A., Peach, R., and Tracy, J. (2008). Juvenile Delinquent Mortgages: Bad Credit or Bad Economy?, Staff Report 341, Federal Reserve Bank of New York. 
Himmelberg, C., Mayer, C., and Sinai, T. (2005). Assessing High House Prices: Bubbles, Fundamentals and Misperceptions, Journal of Economic Perspectives, 19, 4, 67-92.

Jackson, J. R. and Kaserman, D. L. (1980). Default Risk on Home Mortgage Loans: A Test of Competing Hypotheses, Journal of Risk and Insurance, 47, 4, 678-690.

Kau, J. B. and Keenan, D. C. (1995). An Overview of the Option-theoretic Pricing of Mortgages, Journal of Housing Research, 6, 2, 217-244.

Keys, B. J., Mukherjee, T. K., Seru, A., and Vig, V. (2008). Did Securitization Lead to Lax Screening? Evidence from Subprime Loans, available at SSRN: http://ssrn.com/abstract=1093137.

Kiff, J. and Mills, P. (2007). Money for Nothing and Checks for Free: Recent Developments in U.S. Subprime Mortgage Markets, Working Paper 07/188, IMF.

Mayer, C. J. and Engelhardt, G. V. (1996). Gifts, Down Payments, and Housing Affordability, Journal of Housing Research, 7, 1, 59-77.

Mayer, C. J. and Pence, K. (2008). Subprime Mortgages: What, Where, and to Whom? , NBER Working Paper 14083, National Bureau of Economic Research.

Montgomery, B. (2008). Prepared Remarks at the National Press Club, 9 June 2008 , available at

http://portal.hud.gov/portal/page?_pageid=73,3504034\&_dad=portal\&_schem a=PORTAL.

Naredo, J. M., Carpintero, O., and Marcos, C. (2005). El Patrimonio En Vivienda Y Su Distribución Regional, Cuadernos de información económica, 1-23, http://habitat.aq.upm.es/boletin/n34/ajnar.html.

Productivity Commission (2004). First Home Ownership, Inquiry Report 06/2004, Productivity Commission, http://www.pc.gov.au/inquiry/housing/docs/finalreport.

Quercia, R. G., Stegman, M. A., and Davis, W. R. (2007). The Impact of Predatory Loan Terms on Subprime Foreclosures: The Special Case of Prepayment Penalties and Balloon Payments, Housing Policy Debate, 18, 2, 311-344.

RBA (1999c). Semi-annual Statement on Monetary Policy, Reserve Bank of Australia. 
RBA (2003d). Submission to the Productivity Commission Inquiry on First Home Ownership, Occasional Paper 16, Reserve Bank of Australia.

RBA (2005b). Box B: Developments in the Low-doc Loan Market, Reserve Bank of Australia Financial Stability Review, 39-40.

RBA (2007a). Box B: Arrears and Repossessions, Reserve Bank of Australia Financial Stability Review, 54-55.

Rosengren, E. S. (2008). Current Challenges in Housing and Home Loans: Complicating Factors and the Implications for Policymakers, Speech given to The New England Economic Partnership's Spring Economic Outlook Conference on Credit, Housing, and the Consequences for New England, May 30, 2008, available at

http://www.bos.frb.org/news/speeches/rosengren/2008/053008.htm.

Scanlon, K. and Whitehead, C. (2004). International Trends in Housing Tenure and Mortgage Finance, London: Council of Mortgage Lenders.

Tsatsaronis, K. and Zhu, H. (2004). What Drives Housing Price Dynamics: Cross-country Evidence, BIS Quarterly Review, 65-78.

Van den Noord, P. and Heady, C. (2001). Surveillance of Tax Policies: A Synthesis of Findings in Economic Surveys, Economics Department Working Paper 303, OECD.

Vandell, K. D. (1995). How Ruthless Is Mortgage Default? A Review and Synthesis of the Evidence, Journal of Housing Research, 6, 2, 245-264.

Vandell, K. D. and Thibodeau, T. G. (1985). Estimation of Mortgage Defaults Using Disaggregate Loan History Data, Journal of the American Real Estate and Urban Economics Association, 13, 3, 292-316.

Yellen, J. (2008). Opening Remarks to the 2008 National Interagency Community Reinvestment Conference, 31 March, available at http://www.frbsf.org/news/speeches/2008/033.html 